\title{
Notes
}

\section{A Robust Public Debate: Realizing Free Speech in Workplace Representation Elections}

\author{
Kate E. Andrias
}

\section{INTRODUCTION}

The First Amendment stands as a guarantor of political freedom and as the "guardian of our democracy." It seeks to expand the vitality of public discourse in order to enable Americans to become aware of the issues before them and to pursue their ends fully and freely. ${ }^{2}$ As the Supreme Court wrote in the canonical case of New York Times Co. v. Sullivan, the First Amendment's function is to create the "uninhibited, robust and wideopen" public debate necessary for the exercise of self-governance. ${ }^{3}$

The Amendment plays a prominent role in the regulation of workplace representation elections, the process by which unorganized workers decide whether or not to unionize. Since the $1940 \mathrm{~s}$, and particularly since the passage of the Taft-Hartley Act in $1947,{ }^{4}$ Congress and the courts have used the First Amendment to protect the right of employers to campaign against unionization. ${ }^{5}$ Holding that employers may say nearly anything in order to persuade their employees to vote "no" in a union election, the Supreme Court has permitted the National Labor Relations Board to proscribe employer speech only when it contains threats of reprisal or

1. Brown v. Hartlage, 456 U.S. 45,60 (1982).

2. OWEN M. FISS, IRONY OF FREE SPEECH 3 (1996).

3. 376 U.S. 254,270 (1964).

4. Labor Management Relations (Taft-Hartley) Act of 1947, 29 U.S.C. $\S \S 141-187$ (2000).

5. See, e.g., Thomas v. Collins, 323 U.S. 516, 537 (1945) ("[E]mployers' attempts to persuade to action with respect to joining or not joining unions are within the First Amendment's guaranty."). 
coercive promises. ${ }^{6}$ In so ruling, the Court has sought to balance employers' right of free speech, as well as their common-law property and managerial rights, with workers' right to unionize. Yet whether deeming speech to be prohibited or protected, the Court has framed the issue with the First Amendment weighing only on the side of employers. For the most part, existing academic work on union elections has implicitly accepted this approach, viewing employers' rights of speech, property, and management as clashing with workers' statutory right to organize, without invoking any countervailing First Amendment right on behalf of workers. ${ }^{7}$

This Note challenges the Court's approach to the First Amendment for failing both to recognize and to protect the very real speech interests of workers and union organizers at stake in workplace representation

6. See NLRB v. Gissel Packing Co., 395 U.S. 575, 618-19 (1968) (upholding the National Labor Relations Board's ruling that particular employer speech amounted to an unfair labor practice, and holding that "an employer is free to communicate to his employees any of his general views about unionism or any of his specific views about a particular union, so long as the communications do not contain a threat of reprisal or force or promise of benefit"). This Note will refer to the National Labor Relations Board as the NLRB or, more simply, the Board.

7. See, e.g., James A. Gross, A Human Rights Perspective on United States Labor Relations Law: A Violation of the Right of Freedom of Association, 3 EMPLOYEE RTS. \& EMP. POL'Y J. 65, 101 (1999) (applying a human rights perspective, and arguing that the "fundamental human right of freedom of association should trump employer property and speech rights at the workplace"); John Logan, Representatives of Their Own Choosing?: Certification, Elections, and Employer Free Speech, 1935-1959, 23 SEATTLE U. L. REV. 549, 567 (2000) (tracing the history of the Board's protection of employer speech in the election context, and concluding that the Board increasingly chose to privilege employer speech over the right to organize); Clyde W. Summers, Questioning the Unquestioned in Collective Labor Law, 47 CATH. U. L. REV. 791,806 (1991) ("Employer speech has become the primary instrument used by employers to discourage unionization and collective bargaining."); id. at 802-07.

To the extent that labor scholars address the First Amendment in union elections, they focus upon whether employer speech receives the appropriate level of constitutional protection. For the most detailed argument that employer speech does not deserve such extensive protection, see Alan Story, Employer Speech, Union Representation Elections, and the First Amendment, 16 BERKELEY J. EMP. \& LAB. L. 356 (1995). Story concludes that employer speech should not receive constitutional protection, because (1) the workplace does not function as a marketplace of ideas, (2) employer speech is a form of commercial speech, and (3) such speech is coercive. See id. at 456; see also Craig Becker, Democracy in the Workplace: Union Representation Elections and Federal Labor Law, 77 MINN. L. REV. 495, 500-01, 559-65 (1993) (concluding that employers should be stripped of any legally cognizable interest in their employees' election of representatives); Summers, supra, at 806 (arguing that employer speech receives greater protection than constitutionally required and that "[1]imiting employer speech to that constitutionally protected would help restore the original purpose of the Wagner Act"). Other scholars have advocated greater First Amendment protection for ernployer speech. See, e.g., Julius Getman, Labor Law and Free Speech: The Curious Policy of Limited Expression, 43 MD. L. REV. 4, 22 (1984) (arguing for greater First Amendment protection of employer speech, as well as of labor boycotts and picketing); Beth Z. Margulies, NLRB v. Gissel Packing Co.: A Standard Without a Following (The Need for Reappraisal of Employer Free Speech Rights in the Organizing Campaign), 22 WILLAMETTE L. REV. 459 (1986) (showing that Gissel is applied without any consistency, and concluding that such contradictory rulings mean that employer rights should be expanded); Shawn J. Larsen-Bright, Note, Free Speech and the NLRB's Laboratory Conditions Doctrine, 77 N.Y.U. L. REv. 204 (2002) (arguing that restrictions on employer speech under the laboratory conditions doctrine are unconstitutional and in conflict with legislative intent). 
elections. ${ }^{8}$ Building on the work of "democratic" free speech scholars, such as Alexander Meiklejohn, Owen Fiss, and Cass Sunstein, ${ }^{9}$ and applying their theories to a new arena, this Note argues that the Court's exclusive focus on safeguarding employer speech from state incursion leaves society vulnerable to powerful forces of private censorship. ${ }^{10}$ Specifically, the

8. My goal is to deal with the issue of speech not at work generally, but in the context of union-organizing attempts; therefore, a full discussion of whether the grant of common-law managerial and property rights and the ability of employers to silence workers violate the First Amendment absent a unionization attempt is beyond the scope of this Note. A considerable body of scholarship deals with the broader issue, persuasively arguing that the First Amendment should generally protect private-sector workers; there is also some case law supporting this view. See infra note 13. However, there is virtually no scholarship making a First Amendment argument about worker speech specifically within the union-organizing context. Workplace representation elections provide one area in which to interrogate current conceptions of the First Amendment and the workplace. Furthermore, the argument for a revised conception of First Amendment rights in the context of workplace elections is even stronger than in the broad context of employment because union speech is some of the most harshly suppressed speech within the workplace, the union election context is an area in which there is considerable state involvement in the form of regulatory laws and enforcement mechanisms, and the decision of whether or not to unionize has particular relevance to the First Amendment's democratic purposes.

9. See, e.g., Alexander Meiklejohn, Polttical Freedom: The Constitutional POWERS OF THE PEOPLE (1948); FISS, supra note 2; OWEN M. FISS, LIBERALISM DIVIDED (1996) [hereinafter Liberalism Divided]; Cass R. Sunstern, DemocraCy AND THE PROBlem OF FREE SPEECH (1993) [hereinafter SUNSTEIN, DEMOCRACY]; Cass R. Sunstein, Free Speech Now!, 59 U. CHI. L. REV. 255 (1992) [hereinafter Sunstein, Free Speech Now]. For a critique of the democratic theory, see Robert Post, Meiklejohn's Mistake: Individual Autonomy and the Reform of Public Discourse, 64 U. COLO. L. REV. 1109 (1993). My argument also draws from the legal realist work of such scholars as Jack Balkin, who attacks the neutrality of baselines established by the common law and recognizes the state as an important force in constructing a democratic system of free expression. See, e.g., Jack M. Balkin, Some Realism About Pluralism: Legal Realist Approaches to the First Amendment, 1990 DUKE L.J. 375.

10. Scholars concerned about the role of the First Amendment in enabling democracy have focused primarily on campaign finance and control of the media; labor speech-especially speech in union elections--is little more than a footnote in their major works. See, e.g., FISS, supra note 2 (offering no mention of labor speech or union elections); LIBERALISM DIVIDFD, supra note 9 (same); SUNSTEIN, DEMOCRACY, supra note 9, at 33-34 (briefly discussing that New Dealers believed employer spcech was subject to government regulation, but failing to examine the issue in any depth or to discuss workers' speech rights during unionization attempts); see also Balkin, supra note 9, at 387 (identifying the modem-day "paradigmatic free speech issues" as involving access to the media, speech in the political process, and hate speech). This Note suggests that, by failing to treat the issue of speech in workplace elections, First Amendment scholars are missing a critical locus in which speech rights are exercised or denied and through which our democracy and public debate are shaped.

Note, however, that significant scholarship does argue for greater First Amendment protection of worker expression, but in areas other than union elections. For an argument that the First Amendment should provide greater protection of collective labor speech, such as boycotts and strikes, see, for example, James G. Pope, Labor and the Constitution: From Abolition to Deindustrialization, 65 TEX. L. REV. 1071, 1094-96, 1113-18 (1987) [hereinafter Pope, Labor and the Constitution]; and James G. Pope, The Three-Systems Ladder of First Amendment Values: Two Rungs and a Black Hole, 11 HASTINGS CONST. L.Q. 189 (1984). On First Amendment protection for public-sector workers, see, for example, Owen Fiss, Political Freedom and Public Employment, The Antonio Carrillo Flores Lectures 16-26 (Mar. 8, 2001) (transcript on file with author). For an argument supporting greater First Amendment protection for private-sector workers, see sources cited infra note 13. In addition, there has been considerable debate among First Amendment scholars about the role of free speech in workplace harassment cases. See, e.g., Cynthia L. Estlund, Freedom of Expression in the Workplace and the Problem of Discriminatory 
regime governing workplace elections allows employers to suppress worker speech and union messages, even as employers' own speech is protected. In so doing, the current law inhibits robust debate and collective selfgovernance both within the workplace and in society at large, and thereby contravenes the fundamental purpose of the First Amendment.

This Note identifies two distinct, but related, ways in which current doctrine governing workplace elections restricts the freedom of speech. First, it constrains the ability of workers to speak freely and limits the existence of robust debate inside the workplace. The law grants employers extensive rights to campaign against unionization, including the power to compel workers to listen, to suppress their responses, and to exclude the messages of union organizers from the workplace. At the same time, the law fails to protect effectively worker speech. In fact, over the past halfcentury, reprisals suffered by workers who engage in pro-union speech have increased dramatically to well over 10,000 documented cases per year. ${ }^{11}$

Second, the suppression of worker speech and the exclusion of prounion messages within the workplace hinders employees' exercise of free speech and the existence of robust debate outside of the workplace as well. When Americans spend much of their time without rights of expression and collective self-governance, they lose some ability to participate as active citizens in our society's democratic project. Furthermore, because the suppression of worker speech and pro-union messages enables employers to thwart the formation of unions, the ability of individual worker-citizens to engage effectively in public debate through their own collective organizations is impeded.

For these reasons, the First Amendment permits, and indeed requires, us to revise the flawed regime governing workplace representation elections, even if doing so entails some further limits on employer speech. ${ }^{12}$ Toward that end, this Note will propose a new framework that protects worker speech and union messages, a framework more faithful to the First Amendment's purpose of safeguarding democracy.

Part I of this Note examines the historical development of the "false paradigm," which views employers' First Amendment rights as in tension

Harassment, 75 TEX. L. REV. 687 (1997); Eugene Volokh, Comment, Freedom of Speech and Workplace Harassment, 39 UCLA L. REV. 1791 (1992).

11. See COMM. ON THE FUTURE OF WORKER-MGMT, RELATIONS, FACT FINDING REPORT 81 (1994) [hereinafter FACT FINDING REPORT].

12. The notion that the First Amendment allows the state to regulate some speech in order to enable other speech and to further democracy has gained a foothold in several recent concurring opinions authored by Justice Breyer. See infra notes 202-210 and accompanying text. For a discussion of the concept of the state as parliamentarian, capable of intervening to protect speech, see FISS, supra note 2, at 21-25, 28; and OWEN M. FISS, The Right Kind of Neutrality, in LIBERALISM DIVIDED, supra note 9 , at 109, 117-19. 
with statutory collective bargaining rights. It shows that, in the face of concerted pressure from employer groups, the Court, the Board, and Congress increasingly recast property and managerial rights in First Amendment terms while failing to consider the Amendment's democratic purposes. Narrowly focused on protecting individual autonomy from incursion by the state, the Court granted extensive First Amendment protection to employers but neglected the speech interests of workers and union organizers. Part II argues for a revised paradigm: Speech vs. Speech. This Part discusses how employer speech silences workers, and demonstrates that the current doctrine governing union elections fails to provide effective remedies for employer retaliation against pro-union speech, limits the right of workers not to hear employer speech, and constrains the ability of pro-union workers and union organizers to communicate their messages. Part III looks at the purposes of the First Amendment and argues that the jurisprudence on union elections fails to fulfill those purposes, both inside and outside the workplace. Part IV considers what a regime that protects worker and union free speech interests and furthers the democratic aims of the First Amendment might look like. It argues that new regulations on employer speech, as well as regulations to enable worker and union speech, are not only vital public policy, but are both permitted and required by the First Amendment.

\section{DeVElopment of The FALSE PARAdigm OF FrEe SPEECH VS. WORKERS' RIGHT TO ORGANIZE}

Generally speaking, the First Amendment is not thought to protect private-sector employees within the workplace. Under conventional jurisprudence, a private employer may fire a worker for expressing her political views, without raising First Amendment objections, because the private employer is not considered a state actor. ${ }^{13}$ Furthermore, under

13. In contrast, public-sector employees have First Amendment protection from employer retaliation on the basis of their speech if their speech touches on matters of public concern. This is because public employers are considered state actors within traditional First Amendment doctrine. Cf. Connick v. Myers, 461 U.S. 138 (1983) (holding that, although public-employee speech of public concern is protected, a particular public employee's grievance was not a matter of public concern and was therefore unprotected by the First Amendment).

There are strong arguments to be made both against the distinction between public and private employers, and for general First Amendment protections for private-sector employees. See, e.g., Lisa B. Bingham, Employee Free Speech in the Workplace: Using the First Amendment as Public Policy for Wrongful Discharge Actions, 55 OHIO ST. L.J. 341 (1994) (arguing that courts should use the First Amendment to protect employees fired for expression of political views); Terry Ann Halbert, The First Amendment in the Workplace: An Analysis and Call for Reform, 17 SETON HALL L. REV. 42 (1987) (urging the importance of the workplace as a First Amendment forum, and challenging the state action requirement). A few courts have accepted the argument that the First Amendment should serve as a public-policy exemption to the doctrine of employment-at-will. For example, the Third Circuit in Novosel v. Nationwide Insurance Co. held 
American common law, private-sector employees are without general legal protection against arbitrary discipline or discharge. The doctrine of employment-at-will mandates that, in the absence of a contract for a specific duration, an employee may be fired "for good cause, for no cause or even for cause morally wrong." ${ }^{\text {"I }}$ Combined with the Court's narrow focus on protecting the individual speaker from state action, this means that workers effectively have minimal rights of speech at work: An employer has the right to control what messages are expressed on its own property and to fire or discipline workers at will, provided that its actions do not violate other specific statutory or common-law requirements. ${ }^{15}$

One statute that creates protections for worker speech is the National Labor Relations Act (NLRA). ${ }^{16}$ The Act prohibits employers from discriminating against workers for union activity and creates protections for worker speech relating to unionization. ${ }^{17}$ However, these protections are statutory, not constitutional. In contrast, employers are deemed to have a constitutional right to speak against unionization; that is, any constraint placed on employer campaigning by the NLRB is viewed as state action and, therefore, is suspect under the First Amendment. Thus, even though both workers and employees are protected from government interference, employers enjoy a constitutionally protected right to speak while employees within a private-sector workplace effectively do not. This was not always the case: In the early years of the NLRA, employers did not have a

that the First Amendment represents a cognizable cxpression of public policy for purposes of a wrongful discharge claim against a private-sector employer. 721 F.2d 894, 899-90 (3d Cir. 1983). For further discussion, including exploration of state statutes and jurisprudence finding a free speech right for all employees, see Bingham, supra, at 349-54.

14. Payne v. W. \& Atl. R.R. Co., 81 Tenn. 507, 519-20 (1884).

15. See Cynthia L. Estlund, Free Speech and Due Process in the Workplace, 71 IND. L.J. 101 (1995) (arguing that in light of the employment-at-will relationship and the lack of due process in the workplace, employces possess little freedom of speech, and advocating a universal just-cause requirement).

16. 29 U.S.C. $\$ \$ 151-169$ (2000).

17. Employee speech is protected by section 7 of the National Labor Relations Act when it involves "concerted activities" for the purpose of workers" "mutual aid or protection." Id. $\$ 157$. The right to free speech as a form of concerted activity is considered so "fundamental" to the Act that it may not be bargained away by union negotiators. NLRB v. Magnavox Co., 415 U.S. 322 (1974). Moreover, the Court has ruled that the Act includes as concerted activity speech aimed at improving the circumstances of a group of employees, even when the issue is not specific to contract negotiations. See, e.g., Eastex, Inc. v. NLRB, 437 U.S. 556 (1978) (holding that section 7 protection covered a union newsletter that criticized a presidential veto of an increase in the federal minimum wage). In order to trigger the protections of the Act, worker speech must be either entwined with worker group action or involve preparation for such action. See, e.g., NLRB v. Buddies Supermarkets, Inc., 481 F.2d 714 (5th Cir. 1973). In addition, the employer must be aware of the concerted activity. NLRB v. Dawson Cabinet Co., 566 F.2d 1079 (8th Cir. 1977). For further discussion, see Halbert, supra note 13, at 53-56. For an argument that protection of speech under section 7 is too limited, see Cynthia L. Estlund, What Do Workers Want? Employee Interests, Public Interests, and Freedom of Expression Under the NLRA, 140 U. PA. L. REV. 921, 1002 (1992) (arguing for an expansion of the scope of section 7 "to include employee protest directed at the product or service or nonlabor practices of the employer"). 
constitutionally protected right to campaign against unionization, and restrictions on employer speech were not perceived as violations of the First Amendment. ${ }^{18}$

Before examining the current rules governing workplace representation elections and why they raise fundamental First Amendment issues, it is necessary to analyze the development of the concept of employer free speech. A look at this history reveals that, in the years following the passage of the NLRA, employers successfully rephrased Lochner-era arguments about property rights, liberty, and the social status quo in the language of the First Amendment in a bid to maintain control over the workplace. ${ }^{19}$ Over time, Congress and the Supreme Court increasingly accepted these arguments and enshrined the right of employer anti-union campaigning in the First Amendment, while failing to consider issues of worker speech. ${ }^{20}$

18. See infra Section I.A.

19. This history calls into question a common assumption among free speech scholars that the First Amendment has until recently been the province of liberals, and only of late has it been invoked by the economically and socially powerful to suppress equality and democracy. Many First Amendment scholars have remarked on the recent co-optation of the First Amendment: Jack Balkin identifies a "transformation ... overtaking the principle of free speech today." Balkin, supra note 9 , at 393 . He argues that "[b]usiness interests and other conservative groups are finding that arguments for property rights and the social status quo can more and more easily be rephrased in the language of the first amendment by using the very same absolutist forms of argument offered by the left in previous generations." Id.; see also id. ("Just as the concepts of 'liberty' and 'cquality' were co-opted by laissez-faire conservatism in the 1870s, so too 'pluralism' and 'free speech' are slowly being co-opted by the right today."); Robert Post, Introduction to CENSORSHIP and Silencing: Practices of Cultural Regulation 1, 1 (Robert Post ed., 1998) ("Aligned along predictable and venerable divisions separating liberals from conservatives, oriented toward ancient and well-rehearsed chestnuts such as obscenity and national security, the topic [of censorship] promised little of analytic interest. In recent years ... the landscape of censorship has altered dramatically."). Similarly, according to Owen Fiss, for most of the twentieth century "liberals were... united under the banner of free speech," OWEN M. FISS, Introduction to LIBERALISM DIVIDED, supra note 9, at 1,1 [hereinafter FISS, Introduction]; however, this changed "in the seventies ... when the Supreme Court was faced with a number of free speech cases that required it to examine the relationship of political and economic power" and capitalism increasingly began to trump democracy in First Amendment jurisprudence, OWEN M. FISS, Free Speech and Social Structure, in LIBERALISM DIVIDED, supra note 9, at 7, 9-10 [hereinafter FISS, Social Structure].

While First Amendment scholars may be correct that the major free speech debates have only recently focused on the tension between capitalism and democracy, the history of the employer free speech doctrine shows that there is a long tradition of powerful economic interests employing the First Amendment to protect the status quo.

20. Without a doubt, the historical moments and movements are considerably more complicated than I present them here. For a more thorough treatment, see IRVING BERNSTEIN, TURBULENT YEARS: A HISTORY OF THE AMERICAN WORKER, 1933-1941 (1970); and HOWELL JOHN HARRIS, THE RIGHT TO MANAGE: INDUSTRIAL RELATIONS Policies OF AMERICAN BUSINESSES IN THE 1940S (1982). Furthermore, although I look at the legislative debates over the National Labor Relations Act and the development of the employer-speech doctrine, I do not aim to provide a comprehensive legislative history of the Wagner or Taft-Hartley Acts, nor do I fully or adequately trace developments in labor-law doctrine. There are several pieces that provide thorough analyses along those lines. See, e.g., Becker, supra note 7; Story, supra note 7. 


\section{A. Passage of the Wagner Act and the Initial Limits on Employer Campaigning}

While employers today enjoy extensive managerial and property rights over their employees, their rights were much broader prior to the 1930s. In the heyday of substantive due process-the Lochner era-courts repeatedly struck down protective labor legislation on the ground that it unconstitutionally deprived employers of their property rights and their right to liberty under the Fourteenth Amendment. ${ }^{21}$ Following a period of labor strife and turmoil, the Court moved away from this analysis and, in the 1930 s, began to uphold pro-labor legislation. ${ }^{22}$

In 1935, as part of the New Deal, the NLRA was passed..$^{23}$ The law, also known as the Wagner Act, signaled a major shift in the regulation of the workplace and established significant new limits on employer rights. It guaranteed employees "the right to self-organization" 24 and established a system by which the government would certify unions and require employers to bargain collectively with workers. In the years immediately following the Act's passage, the NLRB-the administrative agency established to enforce the Act-did not allow employers to urge their employees not to unionize; any campaigning against unionization by an employer was considered to be an unfair labor practice under the Act. ${ }^{25}$ The Board's determination was based on the economic power wielded by the

21. See, e.g., Lochner v. New York, 198 U.S. 45 (1905) (striking down a New York State statute imposing a ceiling on the hours worked in bakeries on the grounds that New York had exceeded its police powers and interfered with the liberty guaranteed to all persons under the Fourteenth Amendment).

22. See, e.g., NLRB v. Jones \& Laughlin Steel Corp., 301 U.S. 1 (1937) (upholding a state labor law against "yellow-dog" contracts, which conditioned employment on forgoing union membership); Tex. \& New Orleans R.R. Co. v. Bhd. of Ry. \& S.S. Clerks, 281 U.S. 548 (1930) (upholding a federal law that prohibited employers from discharging employees for joining unions). Notably, according to unionists, the rights to organize, boycott, strike, and picket were fundamental rights that predated the New Deal statutes, and their source was to be found in the Constitution, particularly in the First and Thirteenth Amendments. James G. Pope, The Thirteenth Amendment Versus the Commerce Clause: Labor and the Shaping of American Constitutional Law, 1921-1957, 102 COLUM. L. REV. 1, 15 (2002). The change in the Court's approach was a result not only of political mobilization, but also of mass labor unrest; in the years prior to the New Deal, labor implemented its own constitutional vision through then-prohibited strikes and boycotts. See id. at 59-60.

23. National Labor Relations (Wagner) Act, Pub. L. No. 198, 49 Stat. 449 (1935) (codified as amended at 29 U.S.C. $\$ \S 151-169(2000))$.

24. 29 U.S.C. $\$ 157$.

25. For a full discussion of the early jurisprudence on the right of employers to campaign, see Becker, supra note 7, at 535-40 \& nn.174-92. Note that, initially, the Board regularly certified unions without elections. Workers were able to demonstrate support for a union and to gain certification once a majority of workers had signed union cards. $I d$. at 535 . This process limited the ability of employers to influence the outcome of a unionization effort because workers could organize without employer knowledge. Therefore, the issue of whether employers could campaign was less relevant. However, even after the Board began requiring elections as the exclusive means of testing majority support, it barred employers from campaigning. Id. at 536. 
employer. Employer persuasion, it reasoned, could not be separated from coercion. ${ }^{26}$ The ban on employer campaigning was most forcefully stated in the 1942 case of American Tube Bending $\mathrm{Co}^{27}$ In ruling that American Tube had violated the law by urging its employees through letters and mass meetings to vote against the union, the Board explained that the Wagner Act entitled employees to choose "their bargaining representatives free from employer interference" and that the employer had a duty "to maintain complete neutrality with respect to an election., ${ }^{, 28}$

Unable to rely on substantive due process and freedom-to-contract arguments previously available during the Lochner era, employers increasingly began to use First Amendment theories to challenge the federal agency's interference with the workplace. ${ }^{29}$ Initially, both the Board and reviewing federal appeals courts flatly rejected the argument that employer speech deserved First Amendment protection, holding instead that such protection would not serve the Amendment's democratic aims. ${ }^{30}$ Quoting an earlier Second Circuit holding authored by Learned Hand, the Board in American Tube wrote:

“The privilege of 'free speech,' like other privileges, is not absolute; it has its seasons; a democratic society has an acute interest in its protection and cannot indeed live without it; but it is an interest measured by its purpose. That purpose is to enable others to make an informed judgment as to what concerns them, and ends so far as the utterances do not contribute to the result. Language may serve to enlighten a hearer, though it also betrays the speaker's feelings and desires; but the light it sheds will be in some degree clouded, if the hearer is in his power."

26. The Board also "reasoned that employers could not vote and did not appear on the ballot as candidates in representation elections and therefore had no legitimate interest in the outcome." Id. at 536-37.

27. 44 N.L.R.B. 121, 133-34 (1942).

28. Id. at 129.

29. Until the New Deal, employers generally challenged workplace regulation with economic liberty and freedom-to-contract arguments. But the period that saw the passage of the Wagner Act also witnessed a loss of faith in the ideals of laissez-faire capitalism and an end to the Lochner era. Slippery slope arguments against regulation carried less weight; employers were no longer able to assert simply that the sacred right of liberty was being violated, as a new regime of democratic pluralism took hold. Balkin, supra note 9, at 391. As Professor Balkin argues, given the demise of substantive due process and economic liberalism, and the rise of democratic pluralism, "it is not difficult to see why the first amendment [came] to occupy a special position in the pantheon of constitutionally protected liberties." Id. at 392 (citations omitted). Notably, however, Balkin identifies the use of the First Amendment by the socially and economically powerful, in place of liberty arguments, as occurring much later than during the 1930s and 1940s. See supra note 19.

30. For further discussion of the "democratic" purpose of the First Amendment, see infra Section III.A.

31. 44 N.L.R.B. at 133-34 (quoting NLRB v. Federbush Co., 121 F.2d 954, 957 (2d Cir: 1941)). 
Notably, the Board and the Second Circuit did not focus on the narrow question of state action but, rather, looked to the underlying purposes of the First Amendment. ${ }^{32}$

Thus, during the initial years of the NLRA, employer campaigning was wholly proscribed and not considered protected speech within the meaning of the First Amendment. The Board ordered, and federal appeals courts enforced, strict limits on the ability of employers to campaign against unions, ruling that employer campaigning would not further the democratic aims of the First Amendment - to enable citizens to make an " informed judgment as to what concerns them." 33 While the Supreme Court never spoke directly on the issue, it declined to overtum appeals court decisions that enforced Board rulings proscribing all employer campaigning and demanding employers remain neutral with respect to the question of unionization.

\section{B. Emergence of the Employer's Freedom-of-Speech Right}

Despite the initial rejection of their First Amendment claim, employers continued to rely on free speech arguments as they challenged the Board's requirement that they remain neutral during union elections. In addition to making their First Amendment arguments in court, they lobbied vigorously for legislative changes to the NLRA that would enable them to campaign against unionization. ${ }^{34}$ Employers were waging these efforts in the context of rapid organization of American workers: In the fourteen years following the passage of the Wagner Act, total union membership in the United States increased sharply, from about 3.7 million to more than 14.5 million. ${ }^{35}$ Particularly during World War II and the immediate postwar period,

32. While American Tube was an administrative decision, not a Supreme Court ruling, it followed the logic of prior Court cases, particularly a 1940 case, International Ass 'n of Machinists v. NLRB. 311 U.S. 72 (1940). Without ruling on the Board's requirement that the employer maintain total neutrality-unable to take a position on unionization or campaign in any way-the Supreme Court accepted the Board's reasoning about the coercive impact of employer campaigning and upheld the Board's requirement that employers remain neutral toward competing unions. The Court emphasized that employer speech was coercive given the power imbalance in the employment relationship, stating that employer suggestions have a "telling effect among men who know the consequences of incurring that employer's strong displeasure." Id. at 78. 957).

33. American Tube Bending Co., 44 N.L.R.B. at 134 (quoting Federbush Co., 121 F.2d at

34. Logan, supra note 7, at 558-63. For a discussion of the ultimately successful "free speech" amendment and other changes to the NLRA, see infra notes 49-60 and accompanying text.

35. CHRISTOPHER L. TOMLINS, THE STATE AND THE UNIONS: LABOR RELATIONS, LAW, AND THE ORGANIZED LABOR MOVEMENT IN AMERICA, 1880-1960, at 148, 252 (1985). By 1947, unions represented $31.8 \%$ of the "non-farm labor" work force. Id. at 252 . See generally BERNSTEIN, supra note 20 (describing the development of widespread unionism and collective bargaining during the New Deal period). 
American industry was racked by a series of paralyzing strikes. ${ }^{36}$ Responding to the surge in union activity, corporate and business leaders pressured Congress to enact amendments to the NLRA that would constrain further union growth and enable management to reassert control. ${ }^{37}$ In particular, they focused on establishing a right to campaign in union elections, which they termed a "free speech" right. ${ }^{38}$

Increasingly, the free speech arguments articulated by business interests gained acceptance and began to make their way into court decisions. ${ }^{39}$ In 1941, the issue reached the Supreme Court in the case of NLRB v. Virginia Electric \& Power $\mathrm{Co}^{40}$ The employer, Virginia Electric, challenged the Board's finding that its anti-union speeches amounted to unfair labor practices; it argued that the Board rules were "repugnant to the First Amendment. ${ }^{, 41}$ In order to avoid the First Amendment objections, the Court interpreted the Wagner Act to reach only coercive or threatening speech. That is, the Court made clear that the Board could no longer insist on absolute neutrality by proscribing all employer campaigning. Rather, it would be required to evaluate whether speech was coercive in the context of the totality of the employer's conduct. ${ }^{42}$

Then, in 1945, the Supreme Court explicitly declared in Thomas $v$. Collins that the First Amendment protected employers' speech in union campaigns. ${ }^{43}$ Notably, there were no limits on employer speech actually at issue in Thomas; instead, the case involved the question of whether the state

36. See generally GEORGE LIPSITZ, RAINBOW AT MIDNIGHT 20-22, 99-154, 182 (describing mass strikes and labor unrest during the post-war period).

37. Story, supra note 7, at 358 (citing HARRIS, supra note 20, at 109). Employers sought changes to the legislation that would ensure their right to campaign against unionization, prohibit union security clauses in contracts, create extensive regulation of unions' internal affairs, increase the ability of courts to enjoin strikes, and ban sit-down strikes and boycotts. See HARRIS, supra note 20 , at $109-10$.

38. Much of the business community believed that the power balance in labor relations had been unfairly skewed against management, and correcting that imbalance would involve "guaranteeing employers free speech-that is, the right to issue propaganda during union organizing drives, representation elections, strikes or indeed on any occasion when unionism could be attacked." HARRIS, supra note 20, at 109.

39. One explanation for this shift is provided by Craig Becker. Becker describes the intense political pressure brought to bear against the Board as the New Deal reform period ended. Becker, supra note 7, at 508-10. The Board's practice of certifying unions without conducting an election drew especially fierce opposition, and, in 1939, the Board abandoned this practice and signaled that it would rely exclusively on elections. Id. at 509-12; see also Armour \& Co., 13 N.L.R.B. 567, $572-73$ (1939); Cudahy Packing Co., 13 N.L.R.B. 526, 531-32 (1939). According to Becker, "The Board's placement of the contest over union representation in an exclusively electoral framework lent new power to employers' arguments that their campaign rhetoric belonged at the core of the liberties protected by the Constitution." Becker, supra note 7, at 543 .

40. 314 U.S. 469 (1941).

41. Id. at 477 .

42. Id. at $477-78$ (citing Int'l Ass'n of Machinists v. NLRB, 311 U.S. 72, 78 (1940)).

43. 323 U.S. 516,537 (1945). 
of Texas could suppress union speech. ${ }^{44}$ But rather than limiting its holding to that question, the Court went out of its way to establish that employers had rights to campaign freely: "[E]mployers' attempts to persuade to action with respect to joining or not joining unions are within the First Amendment's guaranty." ${ }^{, 45}$ Although citing Virginia Electric as precedent for this proposition, Thomas, in fact, represented the first time the Court was explicitly finding such a First Amendment right. ${ }^{46}$ The Court noted that employer speech was subject to some limits, but it emphasized that the speech deserved broad protection: "When to this persuasion other things are added which bring about coercion, or give it that character, the limit of the right has been passed. But short of that limit the employer's freedom cannot be impaired." ${ }^{, 47}$ Thus, with little explanation by the Court for the jurisprudential shift, "freedom of speech" had now firmly entered the lexicon of Court jurisprudence on union elections.

\section{The 1947 Taft-Hartley Act: Codifying Employer "Free Speech" While Restricting Employee Expression}

Following Virginia Electric and Thomas, employers continued to advocate for changes to the NLRA that would codify their judicially granted right to campaign against unionization. ${ }^{48}$ With the enactment of the Taft-Hartley Act in June 1947, employer groups and their congressional allies achieved their goal of a free speech amendment to the NLRA. ${ }^{49}$ The new provision, section $8(\mathrm{c})$, stated:

44. Thomas involved a Texas statute that required labor organizers to register and obtain organizers' cards before soliciting members. Id. at 519-20 n.1. Texas officials arrested and convicted of contempt a union leader who traveled to the state and gave a speech without registering and in violation of a restraining order. The Court overtumed the union leader's conviction on First Amendment grounds. Id. at 543. For a more detailed discussion of Thomas, see Becker, supra note 7, at 543-45; and Story, supra note 7, at 376-78.

45. Thomas, 323 U.S. at 537.

46. See Becker, supra note 7, at 543-44.

47. Thomas, 323 U.S. at 537-38 (citations omitted).

48. The Roosevelt Court and the Board were deemed unpredictable by employer groups. HARRIS, supra note 20, at 109.

49. In addition to the free speech amendment, the Act contained significant new restrictions on union activity. For example, the new section 2(3) withdrew the right to organize from independent contractors and supervisors. Labor Management Relations (Taft-Hartley) Act, ch. 120, sec. 101, $\$ 2(3), 61$ Stat. 136, 137 (1947). Changes to section 7 made explicit that employees have the right to refrain from union activity, $\$ 7,61$ Stat. at 140 , and the new section 14(b) enabled states to outlaw the union shop, $\S 14(\mathrm{~b}), 61$ Stat, at 151 . The new section 8 (b) outlawed certain forms of concerted activity, including secondary boycotts, and enabled employers to sue in federal court to enjoin unprotected strikes and boycotts. $\$ 8(\mathrm{~b}), 61$ Stat. at 141-43. For further discussion, see ARCHIBALD COX ET AL., LABOR LAW 87-92 (13th ed. 2001); and HARRIS, supra note 20, at 1118-27. The Taft-Hartley Act was bitterly opposed by labor unions and other liberals; it was vetoed by President Truman and passed over his veto. COX ET AL., supra, at 88. 
The expressing of any views, argument, or opinion, or the dissemination thereof, whether in written, printed, graphic or visual form, shall not constitute or be evidence of an unfair labor practice under any provisions of this act, if such expression contains no threat of reprisal or force or promise of benefit.

The report of the House Committee on Education and Labor that accompanied the Taft-Hartley Bill maintained that the changes were rooted in the Constitution: "[The bill] guarantees, to employees, to employers, and to their respective representatives, the full exercise of the right of free speech." 51

Throughout the debates, senators and congressmen emphasized that the free speech amendment would protect one of "the fundamentals of liberty." $" 52$ However, a holistic reading of the debates and their historical context reveals that the liberty at issue was the employers' freedom to campaign against unionization, and the speech referred to was that of employers alone. While the amendment was stated in neutral terms, and purported to guarantee the speech rights of workers and union representatives as well as employers, it was intended specifically to codify the speech rights given to employers in Thomas and to overrule such employer-restrictive administrative decisions as American Tube. ${ }^{53}$ Moreover, the bill's proponents expressed virtually no concern about how the legislation might affect worker speech or public debate.

Indeed, the adoption of the Taft-Hartley Act was driven by employers' efforts to reassert their managerial and property rights over the workplace ${ }^{54}$ and to rein in the rising political influence of labor. ${ }^{55}$ Legislators explicitly stated that changes in the bill-such as bans on secondary and mass picketing, the increased ability of courts to enjoin strikes, and the employerspeech provision-were aimed at constraining collective action by workers in order to reduce labor strife. ${ }^{56}$ They also made clear that the bill sought to

50. $\S 8(\mathrm{c}), 61$ Stat. at 142 (codified as amended at 29 U.S.C. $\S 158(\mathrm{c})(2000))$.

51. H.R. REP. NO. 80-245, at 6 (1947), reprinted in 1 NLRB, LEGISLATIVE HISTORY OF THE LABOR MANAGEMENT RELATIONS ACT, 1947, at 292, 297 (1948) [hereinafter LMRA LEGISLATIVE HISTORY]. The Act's proponents cited Thomas as evidence that to include a free speech guarantee in the Act would confirm a preexisting constitutional right. S. REP. NO. 80-105, at 23 (1947), reprinted in 1 id. at $407,429$.

52. 93 CONG. REC. 5094 (daily ed. May 9, 1947) (statement of Sen. McClellan), reprinted in 2 id. at $1347,1432$.

53. Becker, supra note 7, at 546 (citing H.R. REP. NO. 80-245, at 84, reprinted in 1 LMRA LEGISLATIVE HISTORY, supra note 51, at 292, 375, and S. REP NO. 80-105, at 23, reprinted in 1 $i d$. at 407,429 ). The Senate Report explicitly stated that it believed the Board's interpretation of Thomas and employer free speech rights to be "too restrictive." S. REP. NO. 80-105, at 23, reprinted in 1 LMRA LEGISLATIVE HISTORY, supra note 51, at 407, 429-30.

54. See HARRIS, supra note 20 , at 59-60, 109-25.

55. LIPSITZ, supra note 36, at 173.

56. See H.R. REP. NO. 80-245, at 6, reprinted in 1 LMRA LEGISLATIVE HISTORY, supra note 51, at 292, 297; House Bill Likely To Curb Walkouts, N.Y. TIMES, Feb. 21, 1947, at 3. 
limit the participation of unions in the public debate. One proposal advocated by Representative Hartley would have prohibited newspaper editorial writers from membership in the American Newspaper Guild. Hartley was explicit that his goal was to censor pro-union and leftist messages. By preventing opinion writers from becoming union members, Hartley reasoned, "people, at least through the editorials, will be able to get honest opinions, not influenced by communistic influence.,"57 Business leaders agreed. They saw the Taft-Hartley Act as a way to prevent the continual mobilization of political opinion on the part of labor leaders. Without such changes, one business leader stated, "it is inevitable that we will drift into a socialist dictatorship." 58

Furthermore, the same senators and representatives who were such staunch advocates of "free speech" in union elections proved to be no strong civil libertarians when the ideas at issue posed a radical critique of the American political system. The free speech amendment was adopted by the Senate just before it voted on and approved an amendment requiring that no union be certified if any of its officers "is or ever has been a member of the Communist Party or by reason of active and consistent promotion or support of the policies, teachings, and doctrines of the Communist Party can reasonably be regarded as being a member of or affiliated with such a party." 59 The other statutory changes, including limits on mass picketing and secondary boycotts, were also motivated, at least in part, by anxiety about the spread of Communism, yet they aimed to constrain workers' expressive activity in a way that reached far beyond any "clear and present danger." 19.

57. H. Walton Cloke, Hartley Outlines Labor Law "Equity," N.Y. TMME, Feb. 26, 1947, at

58. House Bill Likely To Curb Walkouts, supra note 56.

59. 93 CONG. REC. 5095 (daily ed. May 9, 1947), reprinted in 2 LMRA LEGISLATIVE HISTORY, supra note 51, at 1434 . A version of the anti-Communist provision ultimately passed and effectively required union leaders to forswear Communist Party loyalties on penalty of losing NLRA protections. See Labor Management Relations Reporting and Disclosure Act, 29 U.S.C. $\S 504(2000)$.

60. Schenck v. United States, 249 U.S. 47, 52 (1919) (holding that speech could be criminalized only if "the words used are used in such circumstances and are of such a nature as to create a clear and present danger that they will bring about the substantive evils that Congress has a right to prevent"). While the Court tolerated significant limits on speech in the name of fear of communism during the height of the Cold War, see, e.g., Dennis v. United States, 341 U.S. 494 (1951) (applying the "clear and present danger" test, and upholding criminal conspiracy convictions of members of the American Communist Party), broad suppression of radical and even revolutionary political speech has since been repudiated and a liberal attitude toward dissent embraced in the law, see, e.g.; Noto v. United States, 367 U.S. 290 (1961) (holding that membership in the Communist Party is not a sufficient grounds for punishment and that the evidence must show that the defendant's actions were calculated to incite violent overthrow of the government); Yates v. United States, 354 U.S. 298 (1957) (overturning convictions of Communists on the grounds that in order to be guilty of unlawful advocacy, not only must one believe in the violent overthrow of the government, but one must also attempt to incite an audience to engage in such conduct). See also Brandenburg v. Ohio, 395 U.S. 444, 447 (1969) 
Union leaders vehemently opposed the new restraints on collective action and the increased emphasis on employer speech. ${ }^{61}$ Labor supporters recognized that the amendments, and particularly the free speech amendment, would not only restrict workers' right to organize but would also limit workers' freedom of speech and the ability of working people to communicate their political goals effectively. Most prominently, Senator Wagner denounced the free speech amendment, arguing that it would suppress, rather than enhance, the exercise of free speech in American society:

The talk of restoring free speech to the employer is a polite way of reintroducing employer interference, economic retaliation, and other insidious means of discouraging union membership and union activity, thereby greatly diminishing and restricting the exercise of free speech and free choice by the working men and women of America. No constitutional principle can support this ....62

\section{From General Shoe to Gissel: Balancing Employer Free Speech with Employees' Right To Organize}

Despite Senator Wagner's warning about the effect of the Taft-Hartley Act on workers' exercise of free speech, subsequent Board and judicial decisions continued to see the First Amendment only on the side of employers. This is not to say that the Board did not maintain limits on employer speech; it did. However, the Board and reviewing courts continued to justify those limits in terms of their effect on workers' right to organize without identifying any free speech interests on the part of workers.

\footnotetext{
(allowing proscriptions against advocating force only when advocacy has become incitement to "imminent lawless action"). For a general discussion of the Communist cases and the Court's adoption of the liberal position, see HARRY KALVEN, JR., A WORTHY TRADITION: FREEDOM OF SPEECH IN AMERICA 211-26 (Jamie Kalven ed., 1988). For further discussion of suppression of political dissent during the McCarthy era, see ERIC FONER, THE STORY OF AMERICAN FREEDOM 255-62 (1998).

The Taft-Hartley Act should thus be seen as having been shaped by a reactionary movement that curtailed political speech broadly, a move that has since been repudiated. Locating the amendments in the historical context of McCarthyism further supports this Note's argument that the current regime of union elections, as codified by those amendments, administered by the Board, and enforced by the courts, restricts the freedom of speech and robust public debate.

61. See Pressman Attacks Labor Curb Bills, N.Y. TIMES, Jan. 31, 1947, at 5; Louis Stark, Green at Senate Hearing Rejects All Labor Curbs, N.Y. TIMES, Feb. 19, 1947, at 1; see also Pope, supra note 22, at $98-99$.

62. 93 CONG. REC. A895 (1947), reprinted in 2 LMRA LEGISLATIVE HISTORY, supra note 51, at 935, 935 (emphasis added); see also Wagner Is "Proud" of His Labor Act, N.Y. TIMES, Feb. 27, 1947, at 14 .
} 
Ten months after the Act took effect, the Board decided General Shoe, ${ }^{63}$ a decision that has since guided the Board's determination of electoral misconduct. In General Shoe, the Board sought to maintain restrictions on employer campaigning. Circumventing, to some extent, the Taft-Hartley Act's insistence that employer speech did not constitute an unfair labor practice, the Board created a new doctrine that required elections to take place in "laboratory conditions.",64 The Board emphasized the employer's authority over employees, holding that certain extreme employer conduct could poison the necessary laboratory conditions and require that the election be overturned, even if the speech of the employer did not qualify as an unfair labor practice when examined in isolation. ${ }^{65}$ The Board made clear that it saw its task as protecting employees' freedom to choose bargaining representatives. Critically, it did not suggest that employee speech rights might be at play as well.

The Board's focus in General Shoe on examining total conditions to determine whether an election can be overturned remains good law today. But the Supreme Court clarified the standard for evaluating employer speech in NLRB v. Gissel Packing Co ${ }^{66}$ Stating that section 8(c) "merely implements the First Amendment," free speech right to communicate his views to his employees is firmly established and cannot be infringed by a union or the Board." the Court affirmed the constitutional status given to employer speech, it also made clear that the free speech right was not unfettered and must be balanced with the statutory right of employees to associate freely. It noted that the balancing of employee and employer rights must take into "account the economic dependence of the employees on their employers, and the necessary tendency of the former, because of that relationship, to pick up intended implications of the latter that might be more readily dismissed by a more disinterested ear." ${ }^{69}$ While the Court recognized the coercive impact of employer speech and continued to maintain limits on it, once again the Court failed to consider whether any speech rights of workers might be at stake.

63. Gen. Shoe Corp., 77 N.L.R.B. 124 (1948).

64. Id. at 127 (holding that "it is the Board's function to provide a laboratory in which an experiment may be conducted, under conditions as nearly ideal as possible, to determine the uninhibited desires of the employees.... When ... the requisite laboratory conditions are not present ... the experiment must be conducted over again." (citation omitted)).

65. Id.

66. 395 U.S. 575 (1969)

67. Id. at 617 .

68. Id.

69. Id. 


\section{E. Locating Employer Speech Within First Amendment Doctrine}

In sum, the historical development of the one-sided free speech paradigm demonstrates that the Court increasingly protected employer speech under the First Amendment, while it failed to recognize worker speech interests as constitutionally protected. This doctrinal development must be understood not just as a response to employer efforts to reassert control over the workplace and to limit the political influence of unions, but also as having been shaped by broader First Amendment jurisprudence. Following World War I, and during the period discussed above, the Court increasingly limited the ability of the state to restrict speech. In so doing, the Court focused on protecting the individual speaker's autonomy from state incursion. ${ }^{70}$ While this doctrinal development critically expanded protection for the political dissenter, it also entailed a narrow focus on state action, positing the state as the enemy of free speech rather than a potential guarantor of speech rights. ${ }^{71}$

The Court's narrow focus on restraining the state, without considering private censorship or the First Amendment's democratic purpose, can be clearly seen in the union election context. The Court, from Thomas to Gissel, guarded against state (NLRB) encroachments on employers' right of expression and their broader common-law rights of property and managerial control. Through the old Wagner Act and the NLRB, the state was the "enemy" attempting to silence the employer. Any curbs on employer speech by the state were highly suspect. Conversely, employer restrictions on worker speech were seen as lacking state action and, therefore, were beyond the reach of the First Amendment. While the Court allowed some limits on employer expression because of statutory collective bargaining rights, defending the First Amendment meant curbing the stateimposed restrictions on employer speech.

Many labor academics who write about union elections, irrespective of political persuasion, implicitly accept the Court's First Amendment approach. They view employer speech and managerial rights as in tension with workers' statutory right to organize, not with any countervailing free speech right. One progressive labor scholar describes the doctrinal development outlined above as follows: "[T] labor board increasingly protected the employers' right to free speech rather than the workers' right to select bargaining representatives free

70. FISS, Social Structure, supra note 19, at 12; FISS, Why the State?, in LIBERALISM DIVIDED, supra note 9, at $31,37$.

71. FISS, Social Structure, supra note 19, at 13; FISS, supra note 70 , at 37-38. For further discussion and critique of the Court's approach, see infra notes 143-159 and accompanying text. 
from employer interference." ${ }^{, 2}$ The academic debate centers on how much constitutional protection employer speech deserves. Some authors focus on the coercion inherent in employer speech and its commercial nature, demanding stricter limits on such speech, ${ }^{73}$ while their opponents argue that the NLRB's restrictions on employer speech are problematic or unconstitutional. ${ }^{74}$ To the extent that such scholars consider issues of worker speech, they do so within the larger context of workers' right to organize. ${ }^{75}$ In so doing, they implicitly accept the Court's conception of the First Amendment as protecting employer speech from state incursion, but not employee speech from employer incursion.

\section{REVISING THE PARADIGM: SPEECH VS. SPEECH, Within THE WORKPLACE}

This Part reframes the free speech paradigm within workplace representation elections as Speech vs. Speech. First, it shows that a great deal of coercive employer speech is permitted under the current regime, and argues that this employer speech not only limits the statutory rights of workers to unionize, but also silences worker speech and pro-union messages. Second, this Part shows that while the Court has emphasized the primacy of employer free speech, it has failed to prevent employer retaliation against pro-union speech. Third, the Court has interpreted the NLRA so as to limit the right of workers not to hear employer speech. Finally, it has constrained the ability of pro-union workers and union organizers to communicate their messages. In short, Congress, the Board, and the federal courts have created and enforced a doctrine that constrains worker speech, excludes union messages, and prevents a meaningful and free debate from occurring within the workplace. As a result, the current legal regime raises serious First Amendment concerns.

This explicit recognition of speech interests on both sides of the equation builds on the work of First Amendment scholars who have similarly reframed issues ranging from cross burning to pornography to

72. Logan, supra note 7, at 567 (emphasis added); see also James A. Gross, Worker Rights as Human Rights: Wagner Act Values and Moral Choices, 4 U. PA. J. LAB. \& EMP. L. 479, 483 (2002) (critiquing the Taft-Hartley amendments to the Wagner Act, and arguing that " $[t]$ he phrase 'employer free speech' concealed the real policy issue: the extent to which, if at all, employers were to be permitted to exert economic power through speech in regard to employees' choice of and participation in unions"); Summers, supra note 7.

73. See Story, supra note 7 , at $405-36$.

74. See Getman, supra note 7; Larsen-Bright, supra note 7.

75. For example, Becker discusses limits on worker speech and union access during union elections, Becker, supra note 7, at 557-69, but neither connects employer coercion to worker silencing nor lays out an argument for how worker speech should be protected by the First Amendment. 
campaign finance. ${ }^{76}$ Take, for example, the issue of cross burning considered by the Court in R.A.V. v. City of St. Paul, ${ }^{77}$ and again, just recently, in Virginia v. Black. ${ }^{78}$ While a traditional approach would see the First Amendment only on the side of white supremacists being constrained from engaging in racist expressive activity, recent scholarship argues that free speech concerns exist on both sides of the equation: The private action of cross burning not only limits the rights of African Americans to decide where to live and to feel secure in their homes, it also interferes with the speech rights of those citizens by discouraging them from participating in the public debate, and by making them feel less secure when voicing their views. ${ }^{79}$ As this Part demonstrates, speech is relevant on both sides of the equation in union elections as well: Employer campaigning and other rules goverming workplace elections not only inhibit the right to organize but have a silencing effect on workers and union messages.

\section{A. The Silencing Effect of Employer Predictions and Veiled Threats}

To understand fully how worker speech is silenced during the course of union elections, we must first recognize how power is exercised in the nonunion workplace. The union drive occurs in a context of employmentat-will, in which the employer has the power to change, unilaterally and without notice, the employee's compensation and the nature of an employee's job. An employer may even terminate the employee without cause; the worker enjoys no general legal protection against arbitrary discipline or discharge. ${ }^{80}$ In short, the employer structures and controls every aspect of the employment relationship. As a result, the worker

76. See generally LIBERALISM DIVIDED, supra note 9; Balkin, supra note 9; Sunstein, Free Speech Now, supra note 9.

77. 505 U.S. 377 (1992). Note that the Court ultimately decided R.A.V. without addressing the constitutionality of cross burning, by holding the statute unconstitutional on its face.

78. No. 01-1107 (U.S. Apr. 7, 2003) (holding that states may criminalize cross burning, as long as prosecutors prove the act was intended as a threat and not as a form of symbolic expression).

79. Notably, the Court in Virginia v. Black implicitly recognized the role of cross burning in silencing African Americans and excluding them from the public debate, as it described how the $\mathrm{Ku}$ Klux Klan used the tactic to terrorize freed blacks in order to prevent them from "participat[ing] in the political process." Id. slip op. at 6 . For further discussion of cross burning and the First Amendment's democratic purposes, see FISS, supra note 12, at 111-20. Similar arguments have been made in favor of regulation that puts caps on campaign contributions (political speech) in order to enhance and equalize the public debate, or that regulates pornography because it silences women. See generally LIBERALISM DIVIDED, supra note 9 . Some of Justice Breyer's recent opinions support the recognition that there can be speech interests on both sides, particularly in the media and electoral context. See infra notes 202-210 and accompanying text.

80. See supra notes 14-15 and accompanying text. See generally Richard A. Epstein, $A$ Common Law for Labor Relations: A Critique of the New Deal Labor Legislation, 92 Y ALE L.J. 1357 (1983) (arguing that labor relations could be better governed through the private law of contract and tort). 
experiences any employer statements against unionization and any employer directives to remain silent from a position of relative powerlessness.

In theory, the NLRA prohibits employers from threatening employees about the repercussions of unionization or from promising benefit enhancements as an inducement not to unionize; the Court, recognizing the coercive power of employers, has found that irrespective of intent, such statements will chill employees' right to organize. The Court's rule against employer threats and promises holds that "an employer is free to communicate to his employees any of his general views about unionism or any of his specific views about a particular union, so long as the communications do not contain a threat of reprisal or force or promise of benefit." ${ }^{\text {81 }}$ However, under current interpretations of the law, employers are allowed to make "objective" predictions. That is, they may frame what would otherwise be an impermissible threat as a prediction about what "might" happen if the employees were to unionize, ${ }^{82}$ even though a direct threat and a prediction might have the same effect on the listener. Employers are thus often able to circumvent the ban on threats by rephrasing their statements as "possibilities."

For example, without risking liability, an employer is free to "predict" that its employees will lose time off; ${ }^{83}$ that unionization will create a perception that the company is strike-prone and unreliable, leading to the loss of customers; ${ }^{84}$ or that unionization could result in layoffs. ${ }^{85}$ The employer may state that the company "might have to tighten up its supervisory and personnel practices and reconsider existing, expensive special benefits. ${ }^{~} 86$ It can suggest that

81. NLRB v. Gissel Packing Co., 395 U.S. 575, 618 (1969) (citation omitted). Employers also may not give benefit increases during elections. See NLRB v. Exch. Parts Co., 375 U.S. 405, 409 (1964) (holding that grants of benefits prior to an election are coercive, and noting that " $[t]$ he danger inherent in well-timed increases in benefits is the suggestion of a fist inside the velvet glove. Employecs are not likely to miss the inference that the source of benefits now conferred is also the source from which future benefits must flow and which may dry up if it is not obliged.").

82. Gissel Packing Co., 395 U.S. at 619 (stating that an employer may make predictions of a possible plant closing after unionization if based on objective facts out of the employer's control).

83. Gen. Elec. Co. v. NLRB, 117 F.3d 627, 632 (D.C. Cir. 1997) (allowing employer statements that workers would likely lose a holiday and two percent vacation bonus under the terms of the union's national agreement).

84. Id. at 633-34; see also Crown Cork \& Seal Co. v. NLRB, 36 F.3d 1130, 1134-35 (D.C. Cir. 1994) (holding protected an employer's prediction that unionization would increase costs, risking the loss of business and consequent layoffs, notwithstanding the employer's failure to explain that such loss of projects was only a risk and not a certainty).

85. Crown Cork \& Seal Co., 36 F.3d at 1140.

86. Paul Weiler, Promises To Keep: Securing Workers' Rights to Self-Organization Under the NLRA, 96 HARV. L. REV. 1769, 1778 (1983) (citing J. LAWSON, HOW TO MEET THE CHALLENGE OF THE UNION ORGANIZER $§ 6(1968)$ ). 
the union would likely demand hefty dues, fines, and assessments, and might take the employees out on a long and costly strike with no guarantee that there would be jobs at the end if replacements had been hired in the meantime; if labor costs and labor unrest became too great, the employer might have to relocate. ${ }^{87}$

Courts have even found that statements such as "I hope you guys are ready to pack up and move to Mexico" are not implied threats of plant closure. ${ }^{88}$ Such statements are all considered protected by the First Amendment as codified in section $8(\mathrm{c}){ }^{89}$ In addition, a threat made to someone outside the bargaining unit (such as a supervisor) promising retaliation against that third party is protected speech, as are threats made against workers to a third party unless it can be shown that the employer intended the workers to hear the speech. ${ }^{90}$ Similarly, employer speech communicating that a third party (such as a customer or a union) will take retaliatory action against employees is not illegal. ${ }^{91}$ In sum, under the free speech provisions of the NLRA, "employers have virtually unlimited opportunities to communicate aggressively with their employees during union campaigns" and these "communications can and often do include distortion, misinformation, threats, and intimidation." $" 92$

Labor scholars have strenuously and extensively critiqued the formalistic distinction between threats and predictions, and the lack of prohibitions upon "third party" coercion. ${ }^{93}$ Yet the willingness of the Board and the Supreme Court to allow employers such wide latitude in expression is not surprising, given the one-sided free speech paradigm that this Note has identified. Although the Court recognizes that employer speech can have a coercive effect and can interfere with employees' right to organize, when the statutory right of collective bargaining is balanced against the constitutional right to speak, it is commonsensical that speech prevail. In

87. Id.

88. NLRB y. Champion Labs., Inc., 99 F.3d 223, 228-29 (7th Cir. 1996).

89. 29 U.S.C. $\$ 158$ (c) (2000). In addition, employer speech is generally considered protected even if it misrepresents and misleads, as long as it lacks any threat of reprisal or coercion. The Board's position on this issue has not been consistent, however. See CoX ET AL., supra note 49, at $155-56$.

90. See Story, supra note 7, at 432-33.

91. Id.

92. Kate L. Bronfenbrenner, Employer Behavior in Certification Election and First Contract Campaigns: Implications for Labor Law Reform, in RESTORING THE PROMISE OF AMERICAN LABOR LAW 75, 82 (Sheldon Friedman et al. eds., 1994).

93. Alan Story, for example, argues that, given the power wielded by the employer, predictions have essentially the same coercive effect as threats, Story, supra note 7 , at $422-32$, and, he contends, protection of third-party threats "completely ignore[s] power relations and hierarchies of the workplace in an almost farcical way," id. at 434-35. Thus, Story, along with others, argues that employer predictions should not be protected under the First Amendment. 
fact, some scholars argue that there should be even fewer restrictions on employer speech. $^{94}$

The problem with this paradigm-Free Speech vs. Right To Organize -is that it ignores the fact that there are speech interests on both sides of the equation and fails to recognize that employer speech has a silencing effect. The very coercion that the Court, the Board, and academics recognize is not just a coercion to stop organizing, but a coercion to be silent. Given the conditions in which the idea of joining a union is circulated-the at-will employment relationship in which workers know they can be fired without cause-employer speech makes it impossible for workers to participate freely and fully in the discussion, due to fear of retaliation. ${ }^{95}$ As they have been repeatedly told by their employer, to express pro-union views and act upon them might lead to a multitude of negative consequences. Fully aware of their precarious position, the workers will understandably choose to refrain from expressing dissenting, pro-union speech.

\section{B. Inadequate Penalties and Enforcement Violate Workers' Freedom of Speech}

The silencing effect of predictions and other protected employer speech is compounded by the fact that the law does not adequately protect employees who speak freely in support of a union. While the law formally protects workers from being disciplined or fired on the basis of their union activity, the Court has held that "[t]he Act does not interfere with the normal exercise of the right of the employer to select its employees or to discharge them." ${ }^{96}$ The employer maintains the authority to terminate employees in the course of union campaigns "for other reasons than ... intimidation and coercion, ${ }^{, 97}$ and the burden of proving that the action was retaliatory is on the plaintiff. ${ }^{98}$

94. For the argument that more employer speech should be allowed, see Getman, supra note 7; and Larsen-Bright, supra note 7.

95. Employer speech also normatively demands silence: By opposing unionization, the employer demands that workers should not have the power to set jointly the terms and conditions of work, and, therefore, that workers should be silent in the workplace. For further discussion, see infra Subsection III.B.1. My description of these two types of silencing draws from OWEN M. FISS, Freedom and Feminism, in LIBERALISM DIVIDED, supra note 9, at 67, 85-86. See also FISS, supra note 2, at 5-26 (discussing the silencing effect of some forms of speech). For an argument that the law of the workplace, because of employment-at-will, does not guarantee due process rights and thus fails to protect free speech generally, see Esthund, supra note 15.

96. NLRB v. Jones \& Laughlin Steel Corp., 301 U.S. 1, 45 (1937).

97. Id. at 46 .

98. 29 U.S.C. $\$ 160$ (c) (2000) (stating that an employee subjected to an unfair labor practice has the burden of showing by a preponderance of the evidence that the employer discriminated against her on the basis of her union activity). 
Moreover, an employee has no private cause of action to challenge her discipline or termination; she may file a charge with the Board, but the Board has discretion over whether or not to prosecute a complaint. ${ }^{99}$ If the Board does prosecute, and an employer is found to have fired a worker in violation of the law, such an employer faces no punitive damages ${ }^{100}$ and may even offset from the back-pay award any wages earned by the worker in the interim. ${ }^{101}$ In addition to the minimal penalties imposed on employers who illegally terminate workers for their union speech, there are significant delays between when a worker files an unfair labor practice charge and when she can hope to get an enforceable court order. The case goes through a four-stage process, averaging three years to complete. ${ }^{102}$

Because penalties for retaliation against union activity are so limited and enforcement is so weak, employers are often not dissuaded from violating the law. ${ }^{103}$ The number of workers who suffer reprisals for union activity each year has increased dramatically over the last half-century. ${ }^{104}$ The data suggest that employers have become increasingly willing to suppress union speech in violation of the federal statute. In recent years, thousands of employees per year have been ordered reinstated as a result of findings that they were discharged on the basis of protected activity, such as solicitation of union support, discussions with coworkers about unionization, and other forms of expressive activity. ${ }^{105}$ The incidence of illegal firings increased from one in every twenty union elections in the 1950 s, to one in every four elections in the 1990s. ${ }^{106}$ According to one

99. See NLRB v. United Food \& Commercial Workers Union, Local 23, 484 U.S. 112, 118 19 (1987).

100. See Ex-Cell-O Corp., 185 N.L.R.B. 107, 108 (1970) (finding that an examiner could not award punitive damages even for a repeat offender).

101. See Phelps Dodge Corp. v. NLRB, 313 U.S. 177, 198-200 (1941); Retailer Delivery Sys., Inc., 292 N.L.R.B. 121, 125 (1988). In 1990, the average back-pay award amounted to $\$ 2749$ per discharge, FACT FINDING REPORT, supra note 11 , at 69 , an amount far too small to serve as a disincentive. Furthermore, as the federal commission established to evaluate the status of worker-management relations noted, there are stiffer sanctions available to employees whose rights are violated under most other federal employment laws including the Civil Rights Act, the Age Discrimination in Employment Act, and the Americans with Disabilities Act, as well as under state employment laws. Under these federal and state laws, the employer is generally liable for financial and psychological harms to the victims, punitive damages for willful misconduct, and attorney's fees of victorious plaintiffs. Id. at 70 .

102. FACT FINDING REPORT, supra note 11, at 69. While it takes an average of three years before an employer is legally obligated to reinstate an employee who has been discharged in violation of the Act, there can be earlier disposition of a charge if there is voluntary agreement between the parties. Id.

103. Weiler, supra note 86 , at 1789-90. Significant case studies support this conclusion. Human Rights Watch, documenting widespread violations of the law, found that "freedom of association is a right under severe, often buckling pressure when workers in the United States try to exercise it." See HuMAN RIGHTS WATCH, UNFAIR ADVANTAGE 7 (2000). See generally id.

104. FACT FINDING REPORT, supra note 11, at 67-68, 81-83.

105. Id. at 67,81 .

106. Id. at 68 . 
scholar, "Union organizing seems to be the most harshly suppressed and frequently adjudicated of all forms of protected workplace speech."107

Given these factors, it is no wonder that most employees believe that pro-union activity results in serious reprisals. ${ }^{108}$ In a 1991 survey, 79 percent of workers polled agreed that it was either "very" likely or "somewhat" likely "that non union workers "will get fired if they try to organize a union." 109 Another study found that "70 percent of employees believe that 'corporations sometimes harass, intimidate, or fire employees who openly speak up for a union.","110 The data suggest that employees are acutely aware of the cost of speaking up for a union against management wishes. Thus, it is only logical that a worker who already believes that prounion speech leads to termination, and who then hears carefully phrased predictions or even outright threats from her employer, would suppress her pro-union speech. Significant empirical work demonstrates that employer campaigning combined with weak enforcement of the statutory right to organize inhibits unionization efforts. ${ }^{111}$ Moreover, case studies and interviews with workers performed by human rights advocates support the intuition that exposure to employers' predictions/threats, combined with fear of retaliation, causes workers to constrain their own speech: Employees consistently describe being silenced due to fear. ${ }^{112}$

107. Estlund, supra note 15 , at 122.

108. Id. at 121 .

109. Richard B. Freeman \& Joel Rogers, Who Speaks for Us? Employee Representation in a Nonunion Labor Market, in EMPLOYEE REPRESENTATION: ALTERNATIVES AND FUTURE DIRECTIONS 13, 29 (Bruce E. Kaufman \& Morris M. Kleiner eds., 1993) [hereinafter EMPLOYEE REPRESENTATION]; see also FACT FINDING REPORT, supra note 11, at 72 (citing and discussing the same study).

110. Paul C. Weiler, Governing the Workplace: Employee Representation in the Eyes of the Law, in EMPLOYEE REPRESENTATION, supra note 109, at 81, 85.

111. Although there is no consensus among empiricists about whether employer speech, in and of itself, unfairly coerces workers or affects the outcome of an election, there is little dispute that when employer anti-union campaigning is combined with weak enforcement against retaliation, workers' ability to organize is drastically reduced. While an early study by Jack Getman concluded that what employers say during an election campaign-including threats, misrepresentations, and promises of benefit improvements-rarely determines or even influences the vote, JULIUS G. GETMAN ET AL., UNION REPRESENTATION ELECTIONS: LAW AND REALITY (1976), many subsequent studies conclude diffcrently, see, e.g., Bronfenbrenner, supra note 92; Richard B. Freeman \& Morris M. Kleiner, Employer Behavior in the Face of Union Organizing Drives, 43 INDUS. \& LAB. REL. REV. 351, 362 (1990). Other scholarship attacks Getman's study on theoretical grounds. See, e.g., Weiler, supra note 86, at 1782-86. For further examples of scholarship challenging Getman's study, see sources cited in Getman, supra note 7, at 10 n.36. For a discussion of the literature, see Story, supra note 7, at 363-64.

112. A nursing-home worker, for example, told Human Rights Watch, "After the firings everybody clammed up.... They were afraid ... . They're afraid of losing their jobs." HUMAN RIGHTS WATCH, supra note 103, at 82. A food-processing worker explained how he altered his pro-union speech due to fear of his employer: "[Management] asked me if I signed a card. I said yes but that I was going to vote against the union." Id at 102; see also YALE LAW SCH. RIGHT To ORGANIZE MONITORING COMM., WHEN BAD LABOR RELATIONS GO GOOD: A ROADMAP FOR LABOR PEACE AT YALE 35-36 \& nn.180-89 (2002), at http://islandia.law.yale.edu/wrp/ (finding 


\section{Compulsion To Listen and Inability To Speak}

The degree to which worker speech is silenced and pro-union messages are excluded during union organizing drives becomes even clearer upon examination of the rest of the representation election doctrine. Under the law, not only are enforcement mechanisms inadequate and employers permitted wide latitude in making predictions about the negative consequences of unionization, but they are also allowed to compel employees to listen to such speech through mandatory "captive audience" meetings, they are permitted to silence workers who offer dissenting opinions during these forced encounters, and they can place restrictions on when and where employees engage in pro-union speech.

According to the Supreme Court, employers may mandate that employees attend anti-union meetings on work time. ${ }^{113}$ These anti-union meetings can take the form of sessions in which there are one or more supervisors and just one worker, as well as mass assemblies. ${ }^{114}$ Attendance at captive audience meetings is compelled: Employees must listen to antiunion speeches or face termination. ${ }^{115}$ Captive audience speeches were initially held to be unlawfully coercive, but were subsequently legalized with passage of the free speech amendment to the NLRA. ${ }^{116}$ They are now considered to be integral to the employer's right to freedom of speech, even though in most other contexts there is no First Amendment right to speak to a captive audience. ${ }^{117}$

widespread intimidation and silencing of workers attempting to organize at Yale-New Haven Hospital and at Yale University).

113. NLRB v. United Steelworkers of Am., 357 U.S. 357 (1958). During the twenty-fourhour period immediately preceding an election, pro- or anti-union group meetings on company time are not allowed. Peerless Plywood Co., 107 N.L.R.B. 427, 429 (1953).

114. See, e.g., HUMAN RIGHTS WATCH, supra note 103 (finding systemic use of the "captive audience" meeting, including individual and mass meetings).

115. Remarkably, the Board has ruled that employees can be terminated for leaving such meetings without permission. Litton Sys., Inc., 173 N.L.R.B. 1024, 1030 (1968).

116. Prior to the Taft-Hartley Act, the Board ruled that employers could not compel employees to listen to anti-union speeches. Clark Bros. Co., 70 N.L.R.B. 802, 804 (1946), enforced as modified, 163 F.2d 373 (2d Cir. 1947). It explained that because the employer wielded its "economic power" to hold an employee audience captive and because the employees were not "free to determine whether or not to receive" the employer's information, the employer committed an unfair labor practice. Id. at 805 . The Board noted that it was not limiting the expression of opinion but only the compulsion to listen, which was not "an inseparable part of . . speech." Id.

Following the passage of the Taft-Hartley Act, and only two years after Clark Bros., the Board reversed course and approved the use of employer captive audience speeches. The decision was based on an interpretation of the Act. The Board wrote that the "language... and its legislative history, make it clear that the doctrine of the Clark Bros. case no longer exists." Babcock \& Wilcox Co., 77 N.L.R.B. 577, 578 (1948). For further discussion, see Becker, supra note 7 , at $557-58$.

117. The Board's determination that it could no longer proscribe captive audience meetings because of the free speech provision of the NLRA (a provision the Supreme Court held to be a mere codification of the First Amendment in $N L R B$ v. Gissel Packing Co., 395 U.S. 575, 617 (1969)) is inconsistent with First Amendment doctrine in other contexts. Generally speaking, the 
The captive audience doctrine unfairly forces workers to listen to employer speech, in ways inconsistent with other areas of First Amendment law. Moreover, the doctrine explicitly allows employers to silence workers and suppress the message of pro-union workers. The employer can legally stifle discussion within the meetings, controlling which viewpoints are aired. For example, the Board has ruled that employers may preemptively exclude union supporters from meetings, ${ }^{118}$ and may eject vocal pro-union workers who deliberately speak out once meetings have begun. ${ }^{119}$ Employers may also terminate employees for insubordination if they evince a concerted plan to speak out during meetings, ${ }^{120}$ or if they ask pro-union questions about the information presented, in violation of a "no question" rule. ${ }^{21}$ The law does not give pro-union employees the right to counterbalance employers' anti-union speech. As the Eighth Circuit has made clear, there is no equal speech right for workers: Required anti-union meetings are not forums in which "employees must be placed in the status of equals in dealing with management." 122

These cases vividly illustrate how the Board and the courts fail to recognize that speech interests exist on both sides of the equation. Worker rights are not considered in terms of free speech. Instead, the rulings emphasize the employer's freedom of speech and its right to control the workplace, balanced against the worker's right to organize. For example, in Boaz Spinning Co. v. NLRB, a pro-union employee was discharged for insubordination arising out of an attempt to speak during a captive audience meeting. ${ }^{123}$ The discharge was upheld by the court, in part because of the employer's right to free speech and without mention of the worker's corresponding speech right: "[The plant manager's] talk was clearly protected by the free speech provisions of the Act and conceded so to be by

Court has held that laws banning speeches to captive audiences do not violate the First Amendment. See, e.g., Frisby v. Schultz, 487 U.S. 474, 487 (1988) (upholding a ban on targeted residential picketing because of the resident's captivity in her home); Lehman v. City of Shaker Heights, 418 U.S. 298, 302 (1974) (upholding a ban on targeted political advertising in buses because the commuters are a captive audience). The decision that the NLRB could not prohibit captive audience meetings because of the "free speech provision" seems even stranger given the Court's holding in FCC v. Pacifica Foundation, 438 U.S. 726 (1978), that the FCC could prohibit certain types of offensive speech on the airwaves because persons receiving broadcasts in their homes are in the position of a captive audience. Whereas listeners in their homes can turn off the radio, workers face termination if they lcave captive audience meetings without permission.

118. See, e.g., F.W. Woolworth Co., 251 N.L.R.B. 1111, 1113 (1980).

119. Hicks Ponder Co., 168 N.L.R.B. 806, 814 (1967).

120. J.P. Stevens \& Co., 219 N.L.R.B. 850, 850 (1975); see also Boaz Spinning Co. v. NLRB, 395 F.2d 512, 514 (5th Cir. 1968) (holding that an employer did not commit an unfair labor practice by discharging an employee who spoke out at a captive audience meeting in violation of the employer's order to remain silent).

121. NLRB v. Prescott Indus. Prods. Co., 500 F.2d 6, 8-11 (8th Cir. 1974) (overruling the Board's judgment that a worker who spoke out in a union meeting and was subsequently terminated for insubordination should be reinstated).

122. $J d$. at 11 .

123. 395 F.2d 512 . 
the Board." 124 In so ruling, the Fifth Circuit claimed to be privileging the rights of employers to speak and to control their workplaces over the statutory right of workers to organize. But in sanctioning the termination of a worker for speaking out during a captive audience meeting, the court was also effectively privileging employer rights over worker speech rights. Essentially, the court ruled that the employer's right to speak and maintain order outweighed the right of the employee to speak.

The ability of employers to stifle pro-union messages and the failure of courts to protect worker speech interests under the First Amendment go beyond the captive audience meeting. Generally speaking, employees are allowed to discuss unionization while at work, but employers can place restrictions on that right if they "can demonstrate that a restriction is necessary to maintain production or discipline." 25 Moreover, under Republic Aviation Corp., the employer can forbid employees from distributing union literature and soliciting coworkers to join the union in working areas of the plant and on work time, as long as the employer places identical restrictions on all forms of solicitation. ${ }^{26}$ Again, the Court balances the rights of employers against workers' right to organize, rather than considering workers' speech rights. ${ }^{127}$

By allowing employers to compel workers to listen, and by permitting employers to actively restrict pro-union messages, Congress, the Board, and courts sanction the silencing of worker and union speech. Moreover, they limit the existence of meaningful debate among workers on the question of unionization. Essentially, the employer may so dominate discussion in the workplace that the employees hear only its message.

124. Id. at 515; see also Prescott Indus. Prods. Co., 500 F.2d at 10 ("Where... an employee's pro-union activity is asserted to have interfered with management's right to maintain order and respect and its right to deliver an anti-union speech, the Board must engage in what we have described as a 'balancing process.' The employees' rights [to engage in concerted activity] are to be weighed against the interests of management in the pursuit of its lawful objectives." (citations omitted)); cf. Mobil Exploration \& Producing U.S., Inc. v. NLRB, 200 F.3d 230, 243 (5th Cir. 1999) (finding a dismissal for speaking out illegal, but still failing to consider workers' rights in terms of free speech: "[T]he employee's right to engage in concerted activity permits some leeway for impulsive behavior, which must be balanced against the cmployer's right to maintain order and respect.").

125. NLRB v. Babcock \& Wilcox Co., 351 U.S. 105, 113 (1956) (citing Republic Aviation Corp. v. NLRB, 324 U.S. 793, 803 (1945))

126. See 324 U.S. at $803 \mathrm{n} .10$ ("Working time is for work. It is therefore within the province of an employer to promulgate and enforce a rule prohibiting union solicitation during working hours." (citation omitted)). Employees may, however, engage in such activity in their off-time in nonworking areas of the workplace, as long as there are no special circumstances making the rule "necessary to maintain production or discipline." Id. at $804 \mathrm{n} .10$ (citation omitted). Similarly, employees may wear union insignia as long as other insignia are allowed and there are no special circumstances making all such insignia impermissible. See id. at 802 n.7.

127. See, e.g., id. at 797-98. 


\section{Union Access and Limits on Debate}

The potential for vigorous and meaningful debate within the workplace is further limited because the law allows employers to exclude union organizers from the workplace. The Supreme Court standard was first articulated in NLRB v. Babcock \& Wilcox Co.:

[A]n employer may validly post his property against nonemployee distribution of union literature if reasonable efforts by the union through other available channels of communication will enable it to reach the employees with its message and if the employer's notice or order does not discriminate against the union by allowing other distribution. ${ }^{128}$

The NLRB and federal appeals courts have interpreted this standard to preclude access of union organizers to almost all workplaces, except when workers live on company property. ${ }^{129}$ Recently, in Lechmere, Inc. v. NLRB, the Supreme Court overturned a Board ruling granting access to a parking lot and made clear that nonemployee union organizers virtually never have the right to enter private property to communicate with unorganized employees. ${ }^{130}$

The limits on union access and on-site solicitation continue even when the employer has violated its own solicitation rules. In Livingston Shirt Co. ${ }^{131}$ decided a few years after the free speech amendment was enacted, the Board departed from earlier holdings and held that employers were allowed to hold captive audience meetings in violation of their own nosolicitation rules without allowing union organizers comparable rights to communicate with employees during work time. ${ }^{132}$ Ironically, while

128. 351 U.S. at 112.

129. See, e.g., Dexter Thread Mills, Inc., 199 N.L.R.B. 543 (1972) (forbidding access to an employer's parking lot even though the property was accessible only by means of a public highway with a forty-mile-per-hour speed limit); $c f$. NLRB v. S\&H Grossinger's Inc., 372 F.2d 26 (2d Cir. 1967) (involving a mountain resort and workers who lived on company property); NLRB v. Lake Superior Lumber Corp., 167 F.2d 147 (6th Cir. 1948) (involving logging camps and workers who lived on company property); Alaska Barite Co., 197 N.L.R.B. 1023 (1972) (involving mining camps and workers who lived on company property).

130. 502 U.S. 527, 540 (1992) ("Because the employees do not reside on Lechmere's property, they are presumptively not 'beyond the reach' of the union's message." (citing Babcock \& Wilcox Co., 351 U.S. at 113)). Notably, the Court in Lechmere, citing Hudgens v. NLRB, 424 U.S. 507 (1976), emphasized that the union organizers had no First Amendment claim and that its determination that there could be a narrow exception to the ban on entry when workers live on company property rested only on the workers' right to organize under section 7 of the NLRB. Lechmere, Inc., 502 U.S. at 533-34. For a discussion of how realization of the First Amendment's democratic aims would both permit and require a different outcome, see infra Part IV.

131. 107 N.L.R.B. 400 (1953).

132. Id. at 409 ("We rule therefore that ... an employer does not commit an unfair labor practice if he makes a preelection speech on company time and premises to his employees and denies the union's request for an opportunity to reply."). 
denying union organizers speech rights, the Board framed its ruling as a victory for the principle of free speech. The Board wrote, "If the privilege of free speech is to be given real meaning, it cannot be qualified by grafting upon it conditions which are tantamount to negation." 133 In NLRB v. United Steelworkers (Avondale), the Supreme Court subsequently upheld the NLRB's affirmation of employer free speech and denial of equal time for union organizers, even when a company is in violation of its own policies against solicitation, and even where employer solicitation is coercive and unlawful. ${ }^{134}$ Thus, the Court specifically held that the right of the union to communicate was not equal to that of the employer. ${ }^{135}$

By virtue of Republic Aviation, Avondale, and Lechmere, both the union's ability to communicate with workers and the ability of workers to communicate with one another are quite limited. Employees may distribute written information about the union and solicit their coworkers' participation only during their nonworking time and in nonworking areas, and paid union organizers have access to workers only in the most particular of circumstances, such as when workers live on company property. Otherwise, they are relegated to whatever public property is closest to the facility. In a landscape increasingly defined by highways and strip malls, this right to communicate is unequal if not illusory. ${ }^{136}$

Thus, the broad protection of employer speech and the extensive power of employers to force workers to listen to anti-union campaigning exist in a context where worker and union speech are severely constrained. When employer predictions and the inadequate protections against retaliation are combined with the rest of the representation election doctrine, the silencing effect is compounded. In sum, Congress, the Board, and the courts have created and enforced a doctrine that enshrines the right of management to campaign against the union, while silencing worker speech and excluding pro-union messages. In so doing, the state has disregarded the First Amendment's goal of creating free and full debate.

133. Id. at 406 .

134. 357 U.S. $357,362-64$ (1958).

135. Id. at 364 . The Court explained:

[T] The Taft Hartley Act does not command that labor organizations as a matter of abstract law, under all circumstances, be protected in the use of every possible means of reaching the minds of individual workers, nor that they are entitled to use a medium of Id. communication simply because the employer is using it.

136. In interviews with human rights advocates, workers point out that the debate within the workplace is skewed. As the food-processing worker told Human Rights Watch, "It would be a lot fairer if the union could come in and talk to us. The company has a big advantage, making people come to meetings and showing videos. A lot of people don't come to union meetings. They're scared the company will know." HUMAN RIGHTS WATCH, supra note 103, at 102. 


\section{UNION ELECTIONS AND THE DEMOCRATIC PURPOSES OF THE FIRST AMENDMENT}

Thus far, this Note has sought to reframe the debate over the regulation of speech within workplace representation elections as Speech vs. Speech, rather than Employer Speech vs. Workers' Right To Organize. In highlighting the coercive impact of employer speech, I have not argued that anti-union campaigning is simply coercion and not speech within the meaning of the First Amendment. ${ }^{137}$ Rather, I have demonstrated how the current regime suppresses worker speech and limits debate. Before examining what a regime that adequately considers workers' speech rights might look like (and whether the First Amendment merely permits or actually requires such changes), it is worth spending a moment looking in more detail at the function of the First Amendment within the Constitution and the American system of government. An examination of the First Amendment's fundamental purpose-to facilitate democracy and collective self-governance-reveals the weakness of the Court's approach and demonstrates the importance of a doctrine that recognizes the speech rights of workers and allows union messages to be heard. That is, the Court's failure to protect worker speech and union messages ultimately contravenes the purposes of the First Amendment, not only within the workplace but also in society more broadly.

\section{A. Uninhibited, Robust and Wide-Open Debate and the Critique of the Autonomy Approach}

One of the most important themes of First Amendment doctrine has been that the Amendment functions "as the guardian of our democracy."138 Indeed, there is considerable support among scholars across the political spectrum for the notion that the purpose of the First Amendment is to enable self-governance. ${ }^{139}$ As Owen Fiss explains, "The law's intention is

137. Cf. Story, supra note 7 , at $405-36$ (arguing that employer campaigning is not speech within the meaning of the First Amendment because it is coercive).

138. Brown v. Hartlage, 456 U.S. 45, 60 (1982); see also Schneider v. New Jersey, 308 U.S. 147, 161 (1939). But see Doe v. Bolton, 410 U.S. 179, 211 (1973) (Douglas, J., concurring) (emphasizing the First Amendment's role in "the autonomous control over the development and expression of one's intellect, interests, tastes, and personality" (emphasis omitted)).

139. See, e.g., Robert H. Bork, Neutral Principles and Some First Amendment Problems, 47 IND. L.J. 1, 20-35 (1971); Harry Kalven, Jr., The New York Times Case: A Note on "The Central Meaning of the First Amendment," 1964 SUP. CT. REV. 191, 208-09; Post, supra note 9, at 111415; see also sources cited supra note 9. That the purpose of the First Amendment is to enable selfgovernance was most famously articulated by Alexander Meiklejohn. See generally MEIKLEJOHN, supra note 9. Note, however, that even scholars who agree on the democratic purposes of the First Amendment draw very different conclusions about what speech should be protected. Bork, for example, requires speech "to deal explicitly, specifically and directly with politics and government." Bork, supra, at 26. Other scholars focus on self-actualization as another goal of the 
to broaden the terms of public discussion as a way of enabling common citizens to become aware of the issues before them and of the arguments on all sides and thus to pursue their ends fully and freely."140 Scholars performing a historical, textual, and structural analysis of the First Amendment support this view. ${ }^{141}$ The free speech guarantee appears as part of a legal instrument largely concerned with establishing the structure of government.

Yet, despite broad consensus on the purpose of the First Amendment, scholars diverge on how best to achieve the goal of enabling selfgovernance-how to determine which speech to protect. Some argue that the best approach is to protect the individual speaker's autonomy from government incursion. ${ }^{142}$ As discussed previously, the Court's approach has been in line with this "autonomy" theory of the First Amendment: Increasingly over time, the Court has protected the individual speaker from the state. ${ }^{143}$ The period from World War I until the early 1970s witnessed a series of profound debates about the role of dissent in society. For civil libertarians, the premise was that "the state was the natural enemy of freedom. It was the state that was trying to silence the individual speaker, and it was the state that had to be curbed."144 During this period, between Schenk ${ }^{145}$ in 1919 and Brandenberg ${ }^{146}$ in 1969, the Court expanded protections for the dissenter, creating what Harry Kalven termed a "worthy tradition." 147 This body of doctrine can be understood as protecting the "street corner speaker" from being silenced by the state, ${ }^{148}$ and the rule that emerged from the period was, in its most basic form, a rule against content regulation: The state cannot silence someone just because it does not like what is being said. ${ }^{149}$

Building on the work of Alexander Meiklejohn, democratic First Amendment scholars have challenged the Court's focus on the individual

First Amendment. See Thomas I. Emerson, Toward a General Theory of the First Amendment, 72 YALE L.J. 877, 879-81 (1963).

140. FISS, supra note 2 , at 3.

141. For such a reading of the First Amendment, see AKHIL REED AMAR, THE BILL OF RIGHTS 20-21 (1998) ("[The First Amendment] sounds in structure and focuses (at least in part) on the representational linkage between Congress and its constituents. On this account, the First Amendment reaffirms the structural role of free speech and a free press in a working democracy."); and id. at 20-26.

142. See, e.g., Post, supra note 9, at 1120 ("[T] from the very aspiration for self-government...."). See generally KALVEN, supra note 60, at 119-236 (celebrating the Court's move over time to protecting the autonomous speaker from state incursion).

143. FISS, Social Structure, supra note 19, at 12; Fiss, supra note 70 , at 37.

144. FiSS, supra note 2, at 2.

145. Schenk v. United States, 249 U.S. 47 (1919).

146. Brandenburg v. Ohio, 395 U.S. 444 (1969).

147. KALVEN, supra note 60.

148. FISS, supra note 19 , at 12.

149. See id. 
speaker's autonomy, arguing that the protection of the street corner speaker from government interference does not necessarily achieve the First Amendment's purpose of safeguarding the democratic system. ${ }^{150}$ These scholars acknowledge that the Court's focus on self-expression, and its attempt to guard against state repression, have served to protect the marginal political dissenter and, therefore, have been essential and valuable parts of the American tradition. ${ }^{151}$ Yet, they argue, the approach fails to recognize how the freedom to speak depends upon the resources at one's disposal and how, given the distribution of political and economic power in society, freedom from state intervention does not always result in a rich public debate. ${ }^{152}$ Autonomy might enhance public debate and promote collective self-determination in a Jeffersonian democracy, "where the dominant social unit is the individual and power is distributed equally."153 But it does not have the same effect in a modern society characterized by gross disparities of power, wealth, and access to information. ${ }^{154}$

In short, democratic free speech scholars argue that, in order to fulfill the purposes of the First Amendment, the Court's focus should not be on protecting the individual street corner speaker from the state. Rather, it should be on enriching public debate and making sure that all views are heard. Under this view,

[t]he state might also have the right to stop the general advocacy of an idea when that advocacy has the effect of interfering with the speech rights of others. In that instance, the state ban on speech does not restrict or impoverish public debate, but paradoxically enough, broadens it, for it allows all voices to be heard. The state acts not as a censor, but rather as a parliamentarian, requiring some to shut up so others can speak. ${ }^{155}$

150. Meiklejohn criticizes Justice Holmes and the focus on autonomy for rob[bing] the amendment of its essential meaning-the meaning of our common agreement that, working together as a body politic, we will be our own rulers. That meaning is the highest insight which men have reached in their search for political freedom. And Mr. Holmes-at least in his "clear and present danger" thinking-misses it.

MEIKLEJOHN, supra note 9, at 75.

151. Jack Balkin urges us to remember that "for most of America's history, protecting free speech has helped marginalized or unpopular groups to gain political power and influence. The first amendment normally has been the friend of left wing values ..." Balkin, supra note 9, at 383; see also FISS, Social Structure, supra note 19, at 13 ("A body of doctrine that fully protects the street corner speaker is indeed an accomplishment of some note....").

152. See, e.g., FISS, Social Structure, supra note 19, at 10; Balkin, supra note 9, at 379 (noting that in our society, "the power of persons to put their messages across loudly and repeatedly because of their economic power and influence effectively silences other, excluded and marginalized voices").

153. FISS, supra note 70 , at 37.

154. Id.

155. FISS, supra note 95 , at $84-85$. 
The democratic theory of the First Amendment has gained explicit support from the Court. Most famously, Justice Brennan wrote in New York Times Co. v. Sullivan that democracy and popular sovereignty require a public debate that is "uninhibited, robust and wide-open." 156 To support the theory, democratic scholars also point to Justice Brandeis's concurrence in Whitney v. California ${ }^{157}$ and the Court's opinion in Associated Press $v$. United States. ${ }^{158}$ These decisions, which form the basis for the democratic theory of the First Amendment, have received new attention in several recent concurring opinions of Justice Breyer. ${ }^{159}$ Critically, Breyer has recognized that there can be speech on both sides of the legal equation and that regulation imposing limited restrictions on particular speech is permissible if such governmental policy enhances public discussion.

\section{B. Workplace Speech, Unions, and the Robustness of Political Debate in Society at Large}

The Court's approach to speech in the workplace representation election, outlined in Parts I and II, illustrates the problem with an "autonomy" approach to free speech: By focusing exclusively on the expressive interests of the employer and on government (NLRB) limits on such expression, the Court has allowed workers to be silenced and union views to be excluded. As demonstrated in Part II, the autonomy approach has failed to ensure any meaningful right of free speech for workers and has failed to enable an "uninhibited, robust and wide-open debate" within the workplace. Rather, it has allowed employees to be routinely silenced and pro-union messages to be excluded. Congress through the Taft-Hartley Act, and the Board and courts through their enforcement capacities, have legitimated and maintained a system in which worker speech and union messages are suppressed.

Critics of this Note might argue that to give more deference to workers and union speech interests would unduly trammel the speech, property, and managerial rights of employers. This Section responds to such objections by arguing that worker speech and union messages must be given more weight relative to employer's property and managerial interests, and must be better balanced with employer speech because of their particular import for the First Amendment's aim of safeguarding democracy.

156. 376 U.S. 254,270 (1964).

157. 274 U.S. 357, 375 (1927) (Brandeis, J., concurring) ("Those who won our independence ... believed that ... public discussion is a political duty; and that this should be a fundamental principle of the American government.").

158. 326 U.S. 1 (1945).

159. See infra notes 202-210 and accompanying text. 


\section{Inside the Workplace}

For the most part, First Amendment scholars have not considered the workplace generally, and the union election specifically, to be a particularly important area for free speech. ${ }^{160}$ Some even treat the workplace as a nonpublic sphere in which government regulation of speech is not problematic. ${ }^{161}$ This Note, however, rejects the notion that the site where Americans spend much of their waking lives is or can ever be outside the domain of public discourse. In fact, the workplace is central to citizenship, identity, and community. ${ }^{162}$ It is not merely a marginal part of the general domain of public discourse; it serves important functions within the larger system of freedom of expression. ${ }^{163}$ For many citizens, particularly the vast majority who are not political activists, the workplace is a main site of discussion about political and social issues in addition to matters of individual personal significance. ${ }^{164}$ Rather than being outside the domain of public discourse, the workplace is a critical locus in which speech rights are exercised and in which the public debate is formed. This is not to argue that there cannot or should not be any restrictions on what workers (or employers) can say while at work, only that the workplace cannot be considered irrelevant to public discourse. While the Court has not offered a coherent theory of freedom of speech within the workplace, it has recognized that employee speech in the workplace should not be wholly beyond the reach of the First Amendment. ${ }^{165}$

Not only is speech within the workplace generally worthy of First Amendment protection, a democratic theory of the First Amendment

160. To the degree that First Amendment scholars do examine the issues of labor speech and speech in the workplace, they tend to focus on protection of public-employee grievances; regulation of harassing speech; and the status of workers' collective action, such as boycotts and pickets. See sources cited supra note 10.

161. For example, Robert Post goes so far as to define the workplace as clearly outside the domain of public discourse, asserting that "an image of dialogue among autonomous selfgoverning citizens would be patently out of place" in the workplace. Robert C. Post, Racist Speech, Democracy, and the First Amendment, 32 WM. \& MARY L. REV. 267, 289 (1991). For a provocative discussion of Post and other academics who treat the workplace as lying outside the realm of public discourse, and of the few commentators who have challenged such conceptions, see Estlund, supra note 10, at 719-20 nn.139-48.

162. For a general discussion of the centrality of work to citizenship, identity, and community, see Vicki Schultz, Life's Work, 100 CoLUM. L. REV. 1881 (2000).

163. See Estlund, supra note 10, at 694, 717-18 (arguing that the workplace is an institution where citizens relate with their fellow citizens; form and exchange opinions about how the workplace is regulated; and gain, or could gain, experience with self-governance). Estlund puts forth a theory in which "the core domain of public discourse is surrounded by satellite domains of discourse within intermediate institutions such as the workplace." $I d$. at 720 .

164. KENT GREENAWALT, FIGHTING WORDS: INDIVIDUALS, COMMUNITIES, AND LIBERTIES OF SPEECH 83 (1995); Kingsley R. Browne, Title VII as Censorship: Hostile-Environment Harassment and the First Amendment, 52 OHIO ST. L.J. 481, 515 (1991).

165. For a discussion of how the Court has treated employee speech within the workplace gencrally, see Estlund, supra note 10, at 708-11. 
demands that workplace speech pertaining to unionization be given particular protection, for several reasons. First, unionization-related speech involves questions of collective self-determination. By deciding whether or not to unionize, workers are deciding whether to establish a representative system of governance at work; they are determining how power should be distributed both in their workplace and in the economy. Because the decision about governance and power is fundamentally political, and because it is a democratic decision usually made by voting, related speech should be protected. After all, the First Amendment protects speech because speech is an "instrument of collective self-determination." unionization gives workers the ability to be heard within the workplace and, therefore, should be seen as speech-enhancing. That is, as employees-atwill, without a collective organization, workers' speech is often inconsequential; it can be disregarded by the employer, leaving employees with no legal or practical recourse. In contrast, unionized employees have a mechanism to make their voices heard through the practice of collective bargaining and collective action. Third, unionization enables greater speech of all kinds within the workplace because unionized workers, unlike employees-at-will, generally cannot be terminated without just cause. ${ }^{167}$ Their job protection and due process rights make them much more likely to speak freely, whether as whistle-blowers or as open critics of their employers. $^{168}$

\section{Outside the Workplace}

Perhaps even more important, at least from the democratic perspective, is that the silencing of worker and union speech during the course of union elections does not just limit speech within the workplace on the question of collective self-determination, but it also limits the robustness of public debate outside the workplace. There are two components to this claim. First, the ability of employers to suppress speech and to thwart unionization efforts means that Americans spend much of their waking lives without any meaningful free speech or democratic participation rights. This limits their experience with collective self-governance-the focus of the First Amendment-and tends to decrease their participation in public life and voting. Second, it narrows the scope of political debate in society: Without the existence of powerful worker organizations, corporate interests increasingly dominate public debate, and the scope of political speech in

166. FiSS, Social Structure, supra note 19, at 13.

167. See Estlund, supra note 15. Because this issue is well-examined by Estlund, I will not discuss it in any depth.

168. Id. 
American society, as well as the health of American democracy, is compromised.

While the link between unionization and the First Amendment's goal of safeguarding the democratic system is largely unexplored, the connection between unionization and democracy is not a new theory. Indeed, the NLRA itself was born out of a belief in the connection between participation rights at work and democratic self-governance. ${ }^{169}$ During the debates over the Wagner Act, themes of democracy, self-government, and citizenship were repeatedly offered as justifications for the Act. ${ }^{170}$ Senator Wagner emphasized the connection between unionization and democracy, stating that the "struggle for a voice in industry through the process of collective bargaining is at the heart of the struggle for the preservation of political as well as economic democracy in America," and positing that if people "know the dignity of freedom and self-expression in their daily lives ... they will never bow to tyranny in any quarter of their national life." $" 171$ The AFL later defended the Wagner Act's constitutionality on the ground that it contributed to democracy by invoking Article IV, Section 4's guarantee that every state be granted a republican form of government: The counsel for the AFL told Congress that "the preservation of industrial democracy [was] essential to the preservation of a republican form of government." 172

Political theorists, most famously Carol Pateman, have given theoretical and empirical support to the claim made by the Act's historical defenders. Workers who have a meaningful role in decisionmaking at work develop a sense of political efficacy that may make them more informed and active citizens in the project of self-governance. ${ }^{173}$ As de Tocqueville

169. See Becker, supra note 7, at 503-04. In labor's view, the legislation was also grounded in the Thirteenth Amendment's ban on slavery and its implicit promise of free labor. See generally Pope, supra note 22 (describing and critiquing the decision of progressive lawyers and legislators who decided to defend the NLRA using the Commerce Clause, rather than a Thirteenth Amendment human rights theory as advocated by the labor movement).

170. Becker, supra note 7, at 503. Becker argues that the model of political democracy provided the framers of the law with powerful images but that the conception has subverted labor's right to representation, "for it rests on a fiction of equality between unions and employers as candidates vying in the electoral arena." Id. at 497.

171. The Ideal Industrial State-as Wagner Sees It, N.Y. TIMES, May 9, 1937, §6 (Magazine), at 8, 23.

172. To Create a National Labor Board: Hearing on S. 2926 Before the Senate Comm. on Education and Labor, 73d Cong. 51 (1934), reprinted in 1 NLRB, LEGISLATIVE HISTORY OF THE NATIONAL LABOR RELATIONS ACT, 1935, at 27, 139 (1959) (statement of William Green, President, AFL).

173. Carole Pateman, Participation and Democratic Theory (1970). Pateman writes:

[I]t is only if the individual has the opportunity directly to participate in decision making and choose representatives in the altemative areas that, under modern conditions, he can hope to have any real control over the course of his life or the development of the environment in which he lives. 
emphasized over a century ago, collective membership organizations serve as schools for democracy. ${ }^{174}$ In particular, aside from elected bodies, unions are some of the most formally democratic institutions in American society, and they therefore provide to workers an important personal experience with representative structures and democratic participation. ${ }^{175}$ Unions historically have fostered political participation among their members, and as they and other membership organizations have become a weaker force in the United States, involvement in civic life and electoral politics has declined. ${ }^{176}$

By no means is unionization the sole method by which workers can learn the values of democracy, nor is it the only means by which there can be participation at work. However, collective bargaining was a right created for the express purpose of building democracy and encouraging civic participation. Even those who doubt the theories of such political scientists as Pateman would acknowledge that daily experience with freedom of speech and representative structures is far more closely tied to democracy and participation in electoral politics than are the art and literature that Meiklejohn conceded were protected by the First Amendment as necessary to voting. ${ }^{177}$ If the project of the First Amendment is to protect speech in

Id. at 110; see also Thomas C. Kohler, The Overlooked Middle, 69 CHI.-KENT L. REV 229, 230 (1993) ("[I]t is the small associations and mediating bodies, where society is realized, that act as the seedbeds for the civic virtues. For it is in them that we learn the habits necessary to sustain democratic political life."). There is also a growing literature supporting both the instrumental and intrinsic value of "employee voice" in workplace governance. See Estlund, supra note 10, at 723.

174. ALEXIS DE TOCQUEVILLE, DEMOCRACY IN AMERICA 517 (J.P. Mayer ed. \& George Lawrence trans., Perennial Classics 2000) (1835) ("In democratic countries knowledge of how to combine is the mother of all other forms of knowledge; on its progress depends that of all the others.... If men are to remain civilized or to become civilized, the art of association must develop and improve among them.").

175. There is no question that American unions have, at times, failed to embody the democratic vision to which the idea of representation at work aspires. For a law reform argument urging greater union democracy, see Clyde W. Summers, Democracy in a One-Party State: Perspectives from Landrum-Griffin, 43 MD. L. REV. 93 (1984). However, just as failures of political democratic systems do not make us reject the notion of democracy, examples of undemocratic unions should not lead us to reject the project of representational democracy at work. Even when labor unions fall short of their democratic potential, they offer workers greater participation rights than does employment-at-will.

176. ROBERT PUTNAM, BOWLING ALONE 31-32, 53, 80-82 (2000) (discussing the decline of political participation in America and the concomitant decline of membership in workplace organizations); see also Theda Skoçpol, Advocates Without Members: The Recent Transformation of American Civic Life, in CIVIC ENGAGEMENT IN AMERICAN DEMOCRACY 461, 462, 498-506 (Theda Skocpol \& Morris P. Fiorina eds., 1999) [hereinafter CIVIC ENGAGEMENT] (arguing that "new civic America [is] largely run by advocates and managers without members," and that this shift away from membership organizations results in greater power and social leverage for elite Americans); Theda Skoçpol et al., A Nation of Organizers: The Institutional Origins of Civic Voluntarism in the United States, 94 AM. POL. SCI. REV. 527 (2000) (arguing that translocal federations, such as federated labor organizations, have historically been central to American civic life, and concluding that revitalization of American democracy might depend on rebuilding such membership organizations).

177. "I believe, as a teacher, that the people do need novels and dramas and paintings and poems 'because they will be called upon to vote." Alexander Meiklejohn, The First Amendment 
order to enable popular sovereignty, then speech that enables democracy deserves special consideration. Conversely, speech that thwarts democracybuilding activity should be considered more suspect.

Organization at work also implicates the First Amendment in that it enables working people to play a larger role in the public debate. By this I do not refer to the ability of workers to speak publicly about the conditions of their work, through boycotts, strikes, or pickets, nor do I mean to refer to public employees' grievances and the question of whether such grievances deserve First Amendment protection, although working conditions arguably are matters of profound public concern. ${ }^{178}$ Rather, I mean that organization enables working people to collectively challenge the corporate agenda in the public arena, whether through pooling their voices, their voting power, or their financial resources. ${ }^{179}$ On topics ranging from health care to NAFTA to the Family Medical Leave Act, individual workers have little ability to be heard: They are alone on the street corner and without the resources of large corporations. In the aggregate, however, they have the power to communicate effectively.

Advocates of the Wagner Act recognized this. They saw collective bargaining as necessary, not only to dismantle economic inequalities and to bring the values of democracy to industry, but also to vindicate workers'

Is an Absolute, 1961 SuP. CT. REv. 245, 263 (quoting Harry Kalven, Metaphysics of the Law of Obscenity, 1960 SUP. CT. REV. 1, 15-16).

178. There is a good deal of scholarship and doctrine debating whether "labor speech" such as boycotts and pickets, as well as public-employee grievances, should be protected under the First Amendment. In Thornhill v. Alabama, 310 U.S. 88 (1940), the Court struck down a state anti-picketing statute and held that the First Amendment protected picketing. The Court declared:

In the circumstances of our times the dissemination of information concerning the facts of a labor dispute must be regarded as within that area of free discussion that is guaranteed by the Constitution.... [L]abor relations are not matters of merc local or private concem. Free discussion conceming the conditions in industry and the causes of labor disputes appears to us indispensable to the effective and intelligent use of the processes of popular government to shape the destiny of modern industrial society. Id. at 102-03 (citations omitted).

The constitutional status of labor speech, and especially labor picketing, has declined sharply since 1940. Labor speech, both in the form of collective action and employee grievances, is now often considered unprotected as economic activity or as a matter of private concern. See, e.g., Connick v. Myers, 461 U.S. 138 (1983) (holding that an employee's grievance, expressed through a questionnaire, was not a matter of public concem and was therefore unprotected by the First Amendment). For an analysis of the constitutional protection of labor picketing, see Pope, Labor and the Constitution, supra note 10, at 1094-96, 1113-18; Cynthia Estlund, Note, Labor Picketing and Commercial Speech: Free Enterprise Values in the Doctrine of Free Speech, 91 Y ALE L.J. 938, 940-4l (1981); and Mark D. Schneider, Note, Peaceful Labor Picketing and the First Amendment, 82 CoLUM. L. REV. 1469, 1475-95 (1982).

179. The Supreme Court indirectly recognized this expressly political role of unions in Abood v. Detroit Board of Education, 431 U.S. 209 (1977), which held that employees cannot be compelled to contribute financially to unions' activities that express political views unrelated to their duties as exclusive bargaining representatives. Without commenting on the merits of the decision, I think it relevant insofar as it underlines the expressly ideological role that unions often play. 
rights of expression in national and local politics. ${ }^{180}$ To some extent, their vision has been borne out. Unions have constituted a fundamental basis for progressive coalitions in American politics and have exercised significant influence in Congress, particularly when it comes to general social legislation. ${ }^{181}$ As they have become weaker in the United States and have come to represent a smaller fraction of the work force, political issues important to the working class have fallen farther from the public screen, ${ }^{182}$ creating a debate that is increasingly dominated by corporate interests. Meiklejohn wrote, "What is essential is not that everyone shall speak but that everything worth saying shall be said." ${ }^{\prime 83}$ With the decline of collective organizations of workers, it becomes increasingly questionable whether everything worth saying shall be said.

\section{A NEW REgIME: PERMISSIBLE AND OBLIGATORY UNDER THE FIRST AMENDMENT}

Given that the current doctrine actually silences worker speech, unfairly compels workers to listen, excludes pro-union messages voiced by both workers and union organizers, and thereby limits the existence of meaningful debate and collective self-governance within and outside of the workplace, what can be done (or must be done) under the First Amendment? This Note answers that, in light of the First Amendment's goal of ensuring robust debate to enable collective self-governance, new regulation to enable worker and union speech during workplace representation elections should be seen as permissible under the First Amendment and, perhaps more importantly, should be required. That is, the First Amendment's commitment to political liberty both allows and mandates the state to intervene in order to achieve a better balance between the competing speech rights of workers and employers.

180. See Becker, supra note 7. Conversely, employers sought to minimize unionization through the Taft-Hartley Act in order to limit the influence of workers in politics. See supra Section I.C.

181. See Richard B. FreEMAN \& James L. MEDOFF, What Do UnIONS Do? 191-206 (1984) (concluding that unions exercise significant power influencing the passage of general social legislation, although they have less power to enact legislation specific to unionism that business opposes). In other countries, unions have played an even greater role in shaping the public debate and in enabling worker speech in society at large. See Kay Lehman Schlozman et al., Civic Participation and the Equality Problem, in CIVIC ENGAGEMENT, supra note 176, at 427, 454 ("In many other democracies, politically engaged trade unions serve as partners of parties of the left in organizing the less affluent."). Moreover, trade unions have played a democratizing effect in such countries as Poland. See generally DENIS MACSHANE, SOLIDARITY: POLAND'S INDEPENDENT TRADE UNION (1981).

182. See Schlozman ct al., supra note 181 , at 457 (noting that the decreasing presence of issues of class and economic justice in American political discourse can be explained in part by "the erosion of the membership and power of labor unions"); id. at 444, 453-57.

183. MEIKLEJOHN, supra note 9, at 26. 


\section{A. The First Amendment Allows Regulation}

Consider first the issue of permissible regulation. ${ }^{184} \mathrm{~A}$ new local or federal law, a revised interpretation of the NLRA, or a state constitutional interpretation that requires access to the workplace for union organizers and off-duty workers; that more stringently protects workers' ability to speak; that eliminates the compulsion to listen; and that places time, place, and manner restrictions on employer speech due to the silencing effect of such speech should be considered permissible under the First Amendment. ${ }^{185}$ Such state action would not violate the First Amendment because it would enhance public debate. ${ }^{186}$ As Justice Black wrote in Associated Press v. United States, "[The First] Amendment rests on the assumption that the widest possible dissemination of information from diverse and antagonistic sources is essential to the welfare of the public.... Freedom ... from governmental interference ... does not sanction repression of that freedom by private interests." 187

\section{Enabling Access}

The question of access is the easiest to reconcile with current Supreme Court doctrine. In Pruneyard Shopping Center v. Robins, the Supreme Court held that a state did not violate the First Amendment, or the Fifth Amendment's Takings Clause, by interpreting its constitution to grant citizens the right of reasonable speech and petition in privately owned shopping malls. ${ }^{188}$ The Court emphasized that the right of property owners to exclude others was subject to limitation. ${ }^{189}$ Moreover, the Court

184. My argument concerning permissive regulation draws from the analysis in Owen $M$. Fiss, The Censorship of Television, in ETERNALLY VIGILANT: FREE SPEECH IN THE MODERN ERA 257 (Lee B. Bollinger \& Geoffrey R. Stone eds., 2002), but applies the concept beyond the media and electoral context, for, as discussed above, public debate and democracy happen not only in the voting booths and in the press but also in the workplace, particularly with regard to the decision of whether or not to unionize.

185. Obviously, a municipal or state law or a state constitutional interpretation that affects the process by which private-sector workers elect unions might raise issues of federal preemption. Although the question of preemption is beyond the scope of this Note, it is important to state that the extent to which local laws are preempted is not an uncontroversial question. Michael Gottesman, for example, makes a persuasive argument that, "contrary to prevailing wisdom, the National Labor Relations Act (NLRA) does not wholly preempt the states' ability to adopt laws facilitating unionization and enhancing employee leverage in collective bargaining with employers." Michael H. Gottesman, Rethinking Labor Law Preemption. State Laws Facilitating Unionization, 7 YALE J. ON REG. 355, 355 (1990). For the purposes of this Note, I will assume no preemption issues and will focus only on the First Amendment implications of such a rule.

186. Throughout this Part, I use the term "state" to refer to official governmental action, whether it be by Congress, state government, or municipal government.

187. Associated Press v. United States, 326 U.S. 1, 20 (1945) (citation omitted).

188. 447 U.S. 74 (1980).

189. Dismissing the takings claim, the Court wrote: 
maintained that California's decision to provide a right of access did not impinge upon the property owners' speech rights. By allowing other citizens to enter the property and engage in free expression, the government was not forcing the property owner to express particular speech. Thus, the Court held that states could, consistent with the First and Fifth Amendments, provide a right of access to private property.

By this same logic, a municipal, state, or federal law allowing union organizers and off-duty workers access to company property in order to communicate messages regarding unionization during a representation election would not violate the First (or Fifth) Amendment. As in Pruneyard, the views expressed by union organizers and workers granted access to the property "[would] not likely be identified with those of the owner,", and "no specific message [would be] dictated by the State to be displayed on appellants' property." have the right of access and anti-union consultants already do have such rights, granted by management. That employers might disagree with the speech of those granted access is not a bar to regulation. Our taxation system is ample evidence that an individual's property can be used to support activities with which he or she disagrees; in fact, this concept is part and parcel of our democratic system. ${ }^{192}$

An objection might be raised that in Pruneyard the property involved was a shopping center, a forum described by the Court as "open to the public to come and go as they please,"193 whereas workplaces are not necessarily open to the public. Yet, this distinction is inapposite for several reasons. Current law already grants significant rights of access to workplaces. For example, employers may not exclude customers or workers on the basis of their race, and they must grant access to government inspectors of all sorts. Moreover, a regulation granting access to workplaces in no way would force private owners to "bear public burdens which, in all fairness and justice, should be borne by the public as a whole."194 Finally, and most important in light of the purposes of the First Amendment, just as the mall rendered the street corner obsolete as a political forum, the modern

It is true that one of the essential sticks in the bundle of property rights is the right to exclude others .... But it is well established that not every destruction or injury to property... has been held to be a "taking" in the constitutional sense. Rather, the determination whether a state law unlawfully infringes a landowner's property in violation of the Taking Clause requires an examination of whether the restriction on private property forc[es] some people alone to bear public burdens which, in all faimess and justice, should be borne by the public as a whole.

Id. at 82-83 (citations omitted).

190. Id. at 87 .

191. Id.

192. For elaboration on this point, see OWEN M. FISS, Building a Free Press, in LIBERALISM DIVIDED, supra note 9 , at $139,156$.

193. Pruneyard Shopping Ctr., 447 U.S. at 87.

194. Id. at 83 (internal quotation marks and citations omitted). 
landscape of highways and office parks has rendered the street corner equally ineffective as a means for communication to workers about unionization. If the goal is to create real deliberation and informed debate on the important political question of unionization, there is no effective forum other than the workplace.

\section{Barring Employers' Captive Audience Meetings and Protecting Worker Expression}

While access is important, the state could do more than simply allow admission to private property. First, the state could outlaw captive audience or other mandatory meetings, which unfairly require one view to be heard, and which compel workers to listen. Prohibiting captive audience meetings in no way would trammel employers' speech rights, even under an autonomy version of the First Amendment. The Court, in other contexts, has repeatedly held that speech to a captive audience is not protected and can be prohibited. ${ }^{195}$ Not only could a ban on captive audience meetings be supported under current doctrine, but such regulation would also further the democratic aims of the First Amendment by allowing free, rather than forced, deliberation.

Second, the state could protect workers' expression of pro-union messages by eliminating the possibility that such comments can be actionable as insubordination, as well as by significantly increasing enforcement mechanisms and sanctions against retaliation on the basis of pro-union expression. These policy measures, too, would be permissible under current doctrine. Increasing penalties on employers for suppressing worker speech in no way would impinge on employers' speech rights; on the contrary, it would facilitate worker speech and would significantly promote meaningful debate and deliberation within the workplace.

\section{Limiting the Silencing Speech of Employers}

Third, consistent with a democratic reading of the First Amendment, states or Congress could intervene to enable worker and union speech and could establish certain limits on employer speech. For example, new regulation could require equal time for pro-union and anti-union messages, perhaps by establishing a series of debates during the pre-election period. Acting as a parliamentarian, the government might also place certain limits on employer speech because of the silencing effect of such speech. The state could require total employer neutrality within the workplace with

195. For a discussion of how regulation of captive audience speeches in the union context is inconsistent with broader First Amendment doctrine, see supra note 117 and accompanying text. 
respect to unionization, as the Board initially did in the first years of its existence. ${ }^{196}$ This would not mean that anti-union speech need be wholly proscribed. Instead, limitations placed upon employer speech should be thought of as time, place, and manner regulations. Employers could still voice opposition to unions through other forums outside the coercive setting of the workplace, such as editorials in public papers. Moreover, employees-because they do not exercise coercive power-could speak out against unions within the workplace.

In the alternative, the law could be changed so as to collapse the current artificial distinction between employer "predictions" and threats, making all such silencing and coercive speech illegal. Such regulations might continue to allow other nonpredictive speech in certain limited contexts. For example, new regulation might permit company representatives to make formal statements opposing unionization or to speak at forums that allowed both sides to present views, while proscribing speeches made by supervisors to the workers they oversee. ${ }^{197}$

The argument that equal time should be established for pro-union messages, and that employer speech should be further constrained because

196. Several states, including New York and California, have in fact enacted laws that attempt to reduce silencing and coercive employer speech. See Prohibition on Use of State Funds and Facilities To Assist, Promote, or Deter Union Organizing, CAL. GOV'T CODE $\$$ 16,64516,649 (West Supp. 2003); An Act To Amend the Labor Law, ch. 601, 2002 N.Y. Laws 1413. These statutes limit the ability of employers to use public money or property to promote or oppose unionization, and are currently being challenged on both First Amendment and federal preemption grounds. A district court recently held the California statute to be preempted by the NLRA. The court did not rule on the First Amendment claim. See Chamber of Commerce v. Lockyer, $225 \mathrm{~F}$. Supp. 2d 1199 (C.D. Cal. 2002).

197. I emphasize the wide array of options for limiting employer speech with the idea that state legislatures should be given latitude to determine what regulation would best achieve the goals of enabling worker speech and achieving a robust debate. I would favor legislation that, in addition to creating a right of access, banning captive audience meetings, and increasing penalties for suppression of speech, would require supervisors to remain neutral with respect to unionization when dealing with employees over whom they have authority. This would leave room for employers to oppose unions in forums unrelated to their own workplaces. I take this position because of current conditions under which workers organize-the powerful coercive effect of employer speech in the employment-at-will context and employees' widespread belief that union speech results in retaliation. Because of these factors, strict limits on employer speech would best enable the individuals who are making the decision about self-governance-the workers themselves - to engage in free and full discussion. The opposition to my favored solution would be twofold. First, some might argue that more limited constraints on the silencing speech of employers could achieve the same goal. In the current typical workplace, I question whether this is true. However, I would not foreclose legislators' ability to come up with other options, such as the debate forums and bans on predictive speech that I suggest in the text, particularly once there are effective sanctions in place and once retaliation for union speech is no longer so prevalent. Second, some might argue that my proposals do not allow robust debate, because they exclude anti-union viewpoints. This is false: Anti-union workers can express their viewpoints and can draw on anti-union expertise, such as the Right to Work Foundation, if they so desire. Morcover, this argument seems far removed from reality. In the contemporary American workplace, employees are acutely aware of their employer's opposition to unionization and have been inundated with anti-union arguments for years. I do not suggest that the balance cannot shift, in the future, if the conditions under which workers organize change. 
of its coercive and silencing effect, is a normative argument based on a democratic reading of the First Amendment. Recall the cases of $R A . V$. and Virginia $v$. Black. There, the argument of democratic free speech scholars was that, by banning supremacists' cross burning, the state was not unconstitutionally constraining free speech and collective selfdetermination; rather, it was protecting the speech rights of its black citizens and enhancing public discussion by ending a pattern of behavior that tended to silence one group and thus distort or skew public debate. ${ }^{198}$ In other words, under the democratic theory of the First Amendment, social equality is critical to free and open debate; by regulating speech that has a silencing, coercive, and subordinating effect, the state advances the goals of the First Amendment.

Although this logic about speech on both sides of the equation differs significantly from the Court's autonomy focus, in that it allows constraints on speech in order to enable uninhibited debate and to facilitate democratic deliberation, ${ }^{199}$ there is some implicit support for such an argument in existing doctrine. In Red Lion Broadcasting Co. v. FCC, for example, the Court emphasized the ability of the government to ensure that all viewpoints are heard; it upheld FCC rules requiring privately owned radio stations to devote a reasonable percentage of broadcast time to public issues and to ensure fair coverage for both sides. ${ }^{200}$ In affirming the FCC's regulations, the Court recognized the ability of the state to intervene in order to ensure the robustness of debate. The FCC later ended the use of the fairness doctrine, and the Court's decisions in the 1970s and 1980s declined to extend the doctrine to other areas. ${ }^{201}$ However, the state's ability to enhance public discussion has recently found support again in the opinions of Justice Breyer. For example, in Turner Broadcasting System v. FCC (Turner II), Breyer emphasized the ability of the government to enhance public discussion and to provide for all viewpoints. ${ }^{202}$ "That policy... seeks to facilitate the public discussion and informed deliberation, which, as Justice Brandeis pointed out many years ago,

198. Fiss, supra note 12, at 117 .

199. See, e.g., Buckley v. Valeo, 424 U.S. 1, $48-49$ (1976) (holding that political expenditures, as protected speech, could not be curbed, and rejecting the argument that "government may restrict the speech of some elements of our society in order to enhance the relative voice of others").

200. The Court wrote, "Just as the Government may limit the use of sound-amplifying equipment potentially so noisy that it drowns out civilized private speech, so may the Government limit the use of broadcast equipment." 395 U.S. 367, 387 (1969).

201. See, e.g., Miami Herald Publ'g Co. v. Tornillo, 418 U.S. 241, 247-58 (1974).

202. 520 U.S. 180, 226-27 (1997) (Breyer, J., concurring in part). Justice Breyer concurred with the majority opinion upholding the provisions of a congressional law that required cable operators to carry the programs of over-the-air broadcasters, thereby guaranteeing that cable subscribers receive those programs, but he articulated a different theory from Justice Kennedy's antitrust theory. Justice Breyer conceptualized the "must-carry" rules as part of a national policy to further debate. For further discussion, see Fiss, supra note 184, at 282-83. 
democratic government presupposes and the First Amendment seeks to achieve." 203

Moreover, Breyer recognized that there can be speech interests on both sides of a regulation, and he wrote that occasionally some speech has to be restricted in order to further other speech: "I do not deny that the compulsory carriage that creates the 'guarantee' extracts a serious First Amendment price. ... This 'price' amounts to a 'suppression of speech.' But there are important First Amendment interests on the other side as well. ${ }^{, 204}$ In such cases, Breyer continued, the Court may uphold a statute regulating speech if it "strikes a reasonable balance between potentially speech-restricting and speech-enhancing consequences."205

Several years later, Justice Breyer, this time joined by Justice Ginsburg, wrote a concurring opinion in a case that upheld a state law imposing dollar limits on campaign contributions. ${ }^{206} \mathrm{He}$ once again focused the Court on the purposes of the First Amendment, and attacked the dissenters for "oversimplifying the problem" and turning a difficult constitutional issue into "a lopsided dispute between political expression and governmental censorship." ${ }^{, 207}$ Pointing out that the case of campaign finance was one in which "constitutionally protected issues lie on both sides of the legal equation," Justice Breyer upheld the law on the grounds that, although it restricted the speech of wealthy contributors, the restriction was limited in scope and was designed by the legislature to increase public debate and to strengthen democracy. ${ }^{208}$

Breyer has addressed the constitutionality of regulations requiring debate and facilitating certain types of speech in the context of the media and of campaign financing; the same logic should be applied when evaluating regulation in the union election context. As demonstrated in Part II, there are speech interests on both sides of the legal equation in workplace representation elections, and as argued in Part III, the silencing of worker speech and the exclusion of union messages under the NLRA have particular consequences for democracy. The imposition of additional, but limited, regulations on employer speech, such as those discussed above, would work to achieve the real purposes of the First Amendment-to facilitate public discussion and informed deliberation. The safeguarding of worker speech and the protection of robust debate are compelling reasons for the state to intervene. ${ }^{209}$ Because such regulation would enable workers

203. Turner II, 520 U.S. at 226-27.

204. Id. at 226 .

205. Id. at 227.

206. Nixon v. Shrink Mo. Gov't PAC, 528 U.S. 377, 399 (2000) (Breyer, J., concurring).

207. Id.

208. Id. at $400,401-03$.

209. Such a regime would not be that far from the approach the Board and courts took prior to the emergence of the one-sided paradigm. See supra Section II.A. 
to speak without fear; would allow pro-union messages to be heard; and would still permit employers to speak in a noncoercive, nonsilencing manner, the speech-enhancing consequences of such actions would outweigh the speech-restrictive ones. ${ }^{210}$

\section{B. The State's Affirmative Obligation}

An understanding of the political aims of the First Amendment does not simply demand that this type of government regulation be permitted under the First Amendment; some form of such state action-specifically a ban on captive audience meetings, greater protection of worker speech from employer retaliation, and access rights for organizers and off-duty workers - should be seen as obligatory. The claim is twofold. First, the First Amendment demands a new regime because the suppression of worker speech and pro-union messages is caused not just by private employer action, but by state action as well. ${ }^{211}$ As demonstrated in Part II, Congress enacted the Taft-Hartley Act with the aim of reducing collective action by workers and the political influence of unions. In the years since, the federal government has administered and enforced a system of regulation that fails to protect worker and union speech. In fact, it explicitly allows workers to be fired for certain speech as insubordination or for refusing to listen to employer speech; it sharply limits the right of workers and unions to communicate their messages. In other words, the employer's autonomy and its power to silence workers, "because it is guaranteed by law, is itself ... an abridgement" ${ }^{212}$ of the freedom of speech.

Second, even if the history is understood as evidencing less direct state action, the commitment to democracy and political freedom embodied in the First Amendment imposes an affirmative obligation on government to intervene in order to ensure protection of worker speech and union messages. Just as the state can censor, nongovernmental entities can exercise "managerial censorship"; this, too, can violate the First Amendment. ${ }^{213}$ The argument that the state has an affirmative obligation to protect union and worker speech from private censorship, while it requires a larger leap from precedent, ${ }^{214}$ is well-grounded in the First Amendment's

210. See Turner II, 520 U.S. at 226-27 (Breyer, J., concurring in part) (stating that the statute at issue should be upheld if the method is not significantly more restrictive than alternative possible methods and if the speech-enhancing consequences would outweigh the speechrestricting ones).

211. For a development of the argument that state action should be conceived of more broadly, see generally Sunstein, Free Speech Now, supra note 9.

212. Id. at 262 (arguing that what seems to be free speech in markets might amount to an abridgement of speech)

213. See Fiss, supra note 184, at 265-67.

214. See, e.g., Hudgens v. NLRB, 424 U.S. 507 (1976) (rejecting the notion that the First Amendment requires a right of access to private workplaces for union organizers). 
commitment to political liberty and democracy, and it finds some implicit support in Court jurisprudence. The Court has occasionally recognized that private actors can threaten public debate just as much as state actors, and that the state may be the only power in society capable of keeping these forces at bay. ${ }^{215}$

The Court's recognition of the state's affirmative obligation to protect speech can be traced to Justice Black's dissent in Feiner v. New York. ${ }^{216}$ In Feiner, Justice Black was adamant that the state was required by the First Amendment to prevent a speaker from being silenced by a crowd who disagreed with his message. Justice Black wrote, "[The police officers'] duty was to protect petitioner's right to talk, even to the extent of arresting the man who threatened to interfere." ${ }^{217}$ Black's insistence that the government has, in some circumstances, an affirmative obligation to protect individuals from being silenced by private citizens later would become majority doctrine. For example, decisions of federal courts throughout the civil rights era made plain that the police had an affirmative responsibility to protect civil rights demonstrators from being silenced by angry white Southerners. ${ }^{218}$

Just as the state had an affirmative obligation to protect the street corner speaker in Feiner, the democratic state in the context of union elections has an affirmative obligation to prevent citizens-in this case, workers-from being silenced by private entities. To borrow Justice Black's words, the government's duty is to protect the workers' "right to talk, even to the extent" of sanctioning and punishing the employers who "threaten to interfere." The decision of the police officer to turn a blind eye to the crowd in Feiner constituted an act of the state and, therefore, a violation of the First Amendment. Similarly, the decision of the NLRB and the Court to turn a blind eye to the silencing of worker speech and to the exclusion of pro-union messages violates the First Amendment. If the state fails to intervene against such repression of speech, then the First Amendment

215. For a more thorough analysis of the doctrinal and theoretical basis for the state's affirmative obligation to act to protect speech, see Owen Fiss, The Idea of Political Freedom, in LOOKING BACK AT LAW's CENTURY 35, 46-52 (Austin Sarat et al. eds., 2002).

216. 340 U.S. 315 (1951). In Feiner, a crowd of people grew restless while listening to Feiner make a controversial political speech. An onlooker threatened to silence Feiner himself if police officers did not do so. The police asked Feiner to stop speaking. When he refused, they arrested him. The Court upheld the conviction and treated the police directive as a reasonable attempt to maintain order. Id. at 320. Justice Black, in dissent, vehemently disagreed with the Court's conclusion.

217. Id. at 327 (Black, J., dissenting); see also Fiss, supra note 215, at 47. The importance of Black's insistence that the state had an affirmative obligation to deny street comer "hecklers" a veto over other citizens' speech was first discussed by KALVEN, supra note 60, at 140-41.

218. See, e.g., Cox v. Louisiana, 379 U.S. 536 (1965) (reversing the convictions of civil rights activists that had been predicated on the hostile reaction that their speech would have elicited from whites); Williams v. Wallace, 240 F. Supp. 100 (M.D. Ala. 1965) (ordering state police to provide protection for Dr. King's march); see also Fiss, supra note 215, at 47. 
ceases to be an instrument of democracy. Current interpretations of the NLRA are unconstitutional-the First Amendment demands their revision-because they fail to create a meaningful debate as they silence worker and union speech.

\section{CONCLUSION}

Current doctrine on workplace representation elections is incompatible with the requirements of a genuine democracy. A product of employers' post-Lochner efforts to maintain control over the workplace and the Court's conventional autonomy approach to the First Amendment, the current doctrine wrongly equates free speech in union elections with a formal right to be free from state interference. In short, Congress, the Board, and the courts together have systematically legitimated and enforced a legal regime that enshrines the free speech rights of employers while failing to acknowledge the presence of labor's free speech interests on the other side of the legal equation.

The current regime suppresses worker speech and union messages within the workplace. Employers are allowed wide latitude to speak under the protection of the First Amendment, even when their speech has a silencing effect. Moreover, they routinely and harshly suppress pro-union speech (in violation of the NLRA but without real penalty), while they exercise their managerial and property rights to exclude union messages and to compel workers to listen. Not only is worker speech inhibited within the workplace, but the current system also limits the scope of public debate outside of the workplace, and decreases the ability of workers to participate in the project of self-governance. This is both because workers are denied rights of expression and participation at work and because the system serves to inhibit the free formation of collective worker organizations capable of participating in the public debate. Because the state has acted to enforce this system (and, simultaneously, has failed to act to remedy it), the state prevents the First Amendment from serving its purpose as our society's main safeguard for, and insirument of, democracy.

A legal framework more faithful to the First Amendment's democratic aims would effectively protect workers' ability to engage in pro-union speech, would eliminate employers' power to compel workers to listen to anti-union speech, and would grant off-duty workers and union organizers access to the workplace and freedom to communicate pro-union messages to workers. Moreover, new local, state, and federal laws creating additional restrictions upon employer speech would be held permissible, even if not compelled by the First Amendment. As Justice Breyer has written, 
regulation that limits speech is allowable when "there are important First Amendment interests on the other side as well."219

Ultimately, new regulation to protect worker speech and union messages is vital public policy. Unless the law is changed, private censorship will continue unrestrained, worker-citizens will continue to be silenced, and valuable public debate in this country's workplaces and in society will continue to be inhibited. Before another 10,000 workers a year suffer retaliation for their union speech, and before the public debate becomes even more dominated by corporate interests, new regulation is needed. Unless we revise the outdated paradigm that systematically undermines basic freedoms, the First Amendment will remain mere rhetoric to millions of workers who are unable to exercise their voices freely. Moreover, without such change, the essential promise of the First Amendment-"our common agreement that, working together as a body politic, we will be our own rulers" ${ }^{\text {220 }}$ - will remain unrealized.

219. Turner Broad. Sys., Inc. v. FCC (Turner II), 520 U.S. 180, 226 (1997) (Breyer, J., concurring in part).

220. MEIKLEJOHN, supra note 9, at 75.

Imaged with the Permission of Yale Law Journal 
***

Imaged with the Permission of Yale Law Journal 